CUADERNOS DE ESTUDIOS GALLEGOS, LXVI Núm. 132 (enero-diciembre 2019), págs. 45-76

ISSN: $0210-847 \mathrm{X}$

https://doi.org/10.3989/ceg.2019.132.02

\title{
COMUNIDADE E REPRESENTACIÓN POPULAR NA GALLAECIA SUEVA E VISIGODA
}

\author{
Martín Fernández CALO \\ Museo das Peregrinacións* \\ ORCID iD: http://orcid.org/0000-0002-9769-3047
}

* Bolseiro do programa 2018 de Formación en materia de patrimonio moble galego da Consellería de Cultura, Educación e Ordenación Universitaria da Xunta de Galicia.

Copyright: @ 2019 CSIC. La edición electrónica de esta revista se distribuye bajo los términos de una licencia de uso y distribución Creative Commons Reconocimiento 4.0 Internacional (CC BY 4.0).

Cómo citar/Citation: Martín Fernández Calo, "Comunidade e representación popular na Gallaecia sueva e visigoda", Cuadernos de Estudios Gallegos, 66, núm. 132 (2019), págs. 4576, https://doi.org/10.3989/ceg.2019.132.02 


\title{
COMUNIDADE E REPRESENTACIÓN POPULAR NA GALLAECIA SUEVA E VISIGODA
}

\section{RESUMO}

En atención ao tema do poder local na Gallaecia tardo-antiga, examínanse os aspectos vencellados á herdanza cultural, a identidade civil e as instancias representativas das comunidades que o compuxeron. Este estudo inscríbese fundamentalmente nos períodos suevo e visigodo, estruturándose en función da influencia que as formas de organización non civil, o réxime municipal romano, as institucións representativas xermánicas e as instancias eclesiásticas tiveron no entramado organizativo das comunidades locais. Ponse de manifesto a diversidade cultural e xurídica que as caracterizou, calibrando a súa evolución e a súa tendencia deica unha paulatina uniformización civil.

Palabras Clave: Gallaecia sueva, visigoda e tardo-antiga, plebs Christiana, municipium romano, conuentus visigodo, Latina munita.

\section{COMUNIDAD Y REPRESENTACIÓN POPULAR EN LA GALLAECIA SUEVA Y VISIGODA}

\section{RESUMEN}

En atención al tema del poder local en la Gallaecia tardoantigua, se examinan los aspectos ligados a la herencia cultural, la identidad civil y las instancias representativas de las comunidades que lo compusieron. Este estudio se adscribe fundamentalmente a los períodos suevo y visigodo, estructurándose en función de la influencia que ejercieron sobre tal entramado organizativo local las formas de organización no civil, el régimen municipal romano, las instituciones representativas germánicas y las instancias eclesiásticas. Se pone de manifiesto la diversidad cultural y jurídica que caracterizó a tales comunidades, calibrando su evolución y su tendencia hacia una paulatina uniformización civil.

Palabras Clave: Gallaecia sueva, visigoda y tardoantigua, plebs Christiana, municipium romano, conuentus visigodo, Latina munita.

\section{COMMUNITY AND POPULAR REPRESENTATION IN SUEVIC AND VISIGOTHIC GALLAECIA}

\begin{abstract}
Attending to the matter of local power in late antique Gallaecia, this article examines the cultural inheritance, civil identity, and representative institutions of the communities which composed it. The research interest is basically limited to the Suevic and Visigothic periods, being arranged according to the influence which non-civic organization, Roman municipal regime, Germanic representative institutions, and ecclesiastical ordering, had over the organizational framework of the local communities. The results show the cultural and juridical diversity which characterized these communities, calibrating their evolution and the tendency which gradually led them to a civil standardization.

Key wORDS: Suevic, Visigothic and late antique Gallaecia, plebs Christiana, Roman municipium, Visigothic conuentus, Latina munita.
\end{abstract}


Recibido/Received: 26/03/2018

Aceptado/Accepted: 17/01/2019

66 Comunidade" é unha verba o suficientemente polisémica como para agochar toda intencionalidade historiográfica; pero a ninguén escapa que "representación", na Tardoantigüidade sueva e visigoda, evoca perante todo o conciliarismo eclesiástico. Estas reunións, de ámbito provincial e xeral, recibían os representantes de cada igrexa diocesana para trataren en común os asuntos do goberno eclesiástico, e eventualmente actualizaren o medrado corpus da lexislación canónica. Porén, os concilios suevos e visigodos foron moito máis ca reunións eclesiásticas. Dende o primeiro concilio de Braga consta a convocatoria rexia, senlleira expresión do cesaropapismo suevo ${ }^{1}$, e a partires da conversión de Recaredo o mesmo acontecerá no costume visigodo ${ }^{2}$. Dende aquela, os concilios de Toledo van acoller a intervención de múltiples dignidades civís, comites e duces dos officia palatino e provinciais ${ }^{3}$, que houberon de traeren á discusión conciliar determinados asuntos dos seus particulares ministerios. Unha longa tradición historiográfica ten querido ver así nestes "concilios nacionais", tanto suevos coma visigodos, verdadeiros órganos de deliberación pública, e mesmo afastados precedentes da representación parlamentaria ${ }^{4}$.

Certamente, non hai representación civil sen comunidade civil. Acontece, neste senso, que tanto o reino suevo coma o visigodo se enfrascaron na progresiva “territorialización” da soberanía monárquica: o esforzo — eventualmente fútil— por uniformizaren o exercicio incontestábel da potestade rexia sobre un territorio

\footnotetext{
1 Segundo expresión de Anselmo López CARreira, O reino medieval de Galicia: contribución a unha historia política, Vigo, A Nosa Terra, 2008, páx. 74; cfr. Concilium Bracarensis I, praefatio.

2 Conc. Toletanum III, praef.

3 Véxase, alén das suscricións conciliares, Luis A. García Moreno, Estudios sobre la organización administrativa del reino visigodo de Toledo, Madrid, Instituto Nacional de Estudios Jurídicos, 1974.

${ }^{4}$ Cfr., para os concilios xerais suevos, Emilio GonzÁLez LóPEz, "A monarquía suevo-galaica e a súa organización eclesiástica", Grial, 42 (1976), páx. 283; Franquelim Neiva SoARES, "Os Concílios Suevos de Braga (561 e 572)", en Erwin Koller e Hugo Laitenberger (eds.), Suevos-Schwaben: das Königreich der Sueben auf der Iberischen Halbinsel (411-585), Tübingen, Gunter Narr Verlag, 1998, páx. 67; para os visigodos, José Moreno CaSADo, "Los concilios nacionales visigodos: iniciación de una política concordatoria", Boletín de la Universidad de Granada, 18 (1946), páxs. 8-19; José OrLandis Rovira, "Las relaciones intereclesiales de la Hispania visigótica"; Communio, 12 (1972), páxs. 432-433. Pode consultarse unha síntese recente en Paul Valdiere, Conciliarism: A History of Decision-Making in the Church, Cambridge, Cambridge University Press, 2012, páxs. 95 e segs.
} 
definido e, polo que agora importa — pois o título deste traballo alude á "comunidade"-, sobre os seus súbditos 5 . Canda menos as noticias visigodas resultan elocuentes neste sentido: así, unha lei de Recesvinto colocaba expresamente baixo a protección do seu código civil á totalidade dos cidadáns (omnes ciues) ${ }^{6}$, evidente sinónimo da gens - evocada noutra coñecida locución política-, considerada canda a patria aut princeps un dos tres piares constituíntes do Regnum ${ }^{7}$.

Emporiso, tales expresións globais da identidade e a representación civil conformaron só senllas facetas superficiais súas na Tardoantigüidade sueva e visigoda. Estes construtos xermánicos herdaron boa parte da súa lexislación e case toda a súa administración da esmorecida Romanidade sobre a que se ergueran, cando a lei e a administración repousaran na ciuitas: a cidade-estado, suxeito local do poder político. Algo así aconteceu tamén nos reinos suevo e visigodo. Foi no seo de cada comunidade local, en efecto, onde a identidade civil e a representación popular materializaron as verdadeiras atribucións que lles conferiría a nosa Tardoantigüidade. Con isto entramos xa no ámbito específico da Gallaecia, de todas e cada unha das comunidades galaicas... E entramos tamén na materia específica do presente estudo.

\section{HisTORIOGRAFÍA}

O poder e as institucións tardo-antigas non constitúen certamente un eido novidoso de investigación histórica, pero tampouco un usual. A historiografía deste tema viviu de feito a súa etapa máis dinámica hai preto dun século, a propósito das controversias institucionalistas suscitadas pola lexislación visigoda. No que ao poder local respecta, esta controversia interesouse fundamentalmente pola herdanza municipal romana no réxime concellil medieval, debatida con entusiasmo por insignes historiadores do dereito ${ }^{8}$, pero case adurmiñada dende aquela na Historia xeral ${ }^{9}$. Os tímidos avances producidos dende a completa, e xa

\footnotetext{
5 Cfr. Karl Zeumer, Historia de la legislación visigoda, Barcelona, Universidad de Barcelona, 1944, páxs. 83-88; Céline MARTin, "In confinio extremis gentibus: la percepción de la frontera en el reino visigodo", Studia Historica (historia antigua), 16 (1998); Pablo C. DíAz MArTínez, "La Hispania visigoda", en Pablo C. Díaz Martínez, Celia Martínez Maza e Francisco Javier Sanz Huesma, Hispania tardoantigua y visigoda, Madrid, Istmo, 2007, páxs. 416-417; íd., El reino suevo (411-585), Madrid, Akal, 2011, páx. 191; López CARreira, O reino..., páx. 78.

6 Liber iudiciorum, I, 1, 3.

7 Véxase, nomeadamente, Martin, "In confinio...”, páx. 270.

8 Nomeadamente, Eduardo PÉRez Pujol, Historia de las instituciones sociales de la España goda, vol. II, Madrid, Fernando Fe, 1896; Eduardo de HinojosA, "El origen del régimen municipal en León y Castilla”, La Administración, s/n (1896), páxs. 3-24; Claudio SÁnCHEZ-Albornoz, Ruina y extinción del municipio romano en España e instituciones que le reemplazan, Buenos Aires, Universidad Nacional de Buenos Aires, 1943.

9 Agás no medievalismo, que tende hoxe, con todo, a estimar o réxime concellil como unha xenuína innovación medieval, soslaiando así o problema da súa ascendencia tardo-antiga: cfr. Julio VALDEÓN BARU-
} 
andada, monografía de L. A. García Moreno arredor da administración visigoda ${ }^{10}$ apenas teñen afectado ás institucións locais. No ámbito específico da Gallaecia contamos hoxe con dúas monografías que en grande medida teñen satisfeito globalmente o rango cronolóxico da nosa Tardoantigüidade, a Gallaecia Gothica de R. Barroso, J. Morín e I. Sánchez, e sobre todo o completísimo Reino suevo de P. C. Díaz Martínez, que malia o seu fundamental contributo comparten indistintamente a mesma atención privilexiada ás estruturas estatais sobre as locais ${ }^{11}$. Non se avanzou moito, en efecto, dende a caracterización xeral que, recén rematada a segunda guerra mundial, o padre P. David soubo debuxar do poder local galaico a través do Parroquial suevo ${ }^{12}$. Sobra agora estendérmonos arredor deste decisivo contributo ou da amplísima influencia — e máis isolada crítica — que ten atopado dende aquela, pois voltaremos insistentemente sobre isto ao longo do presente estudo; pero si pode resultar significativo referírmonos agora a algunhas das novidades que, sobre esta base, se teñen asentado máis recentemente no noso tema particular.

Así, deica o novo milenio, P. C. Díaz Martínez revisitou o Parroquial e a confrontación das igrexas nel consignadas coas cecas visigodas, o que o levou a repensar a permanencia das estruturas socio-políticas locais entrambos os perío$\operatorname{dos}^{13}$. Máis recentemente, dentro da mesma vocación comprensiva a longo prazo entre períodos históricos sucesivos, eu mesmo teño promovido a cuantificación das entidades políticas locais reflectidas polo Parroquial, confrontándoas coas de época romana ${ }^{14}$. Dentro dos meus estudos arredor da historia constitucional da Gallaecia, noutro artigo publicado recentemente nesta mesma revista achegueime xa aos prolegómenos da Tardoantigüidade, ao analizar o rexistro histórico rexional dos séculos III ao $\mathrm{V}$ ao abeiro interpretativo do municipium romano,

QUE, "El origen del concejo abierto en Castilla y León", en Miscel-lània en homenatge al P. Agustí Altisent, Tarragona, Diputació de Tarragona, 1991, páxs. 173-182; José MARQUEs, “Os municípios portugueses dos primórdios da nacionalidade ao fim do reinado de D. Dinis: alguns aspectos", Revista da Faculdade de Letras (Universidade do Porto), 10 (1993), páxs. 71 e segs.

10 García Moreno, Estudios...

11 Díaz Martínez, El reino...; Rafael Barroso Cabrera, Jorge Morín de Pablos e Isabel Sánchez Ramos, "Gallaecia Gothica: de la conspiración del Dux Argimundus (589/590 d.C.) a la integración en el Reino visigodo de Toledo", Idanha-a-Velha, 1 (2015), páxs. 1-156.

12 Pierre DAVID, Études historiques sur la Galice et le Portugal du VIII au XII ${ }^{e}$ siècle, Lisboa-Paris, Portugalia-Les Belles Lettres, 1947, páxs. 45 e segs.

13 DíAz Martínez, "El Parrochiale Suevum: organización eclesiástica, poder político y poblamiento en la Gallaecia Tardoantigua”, en Jaime Alvar (ed.): Homenaje a José María Blázquez, vol. VI, Sevilla, Ediciones Clásicas, 1998; íd., "Acuñación monetaria y organización administrativa en la Gallaecia tardoantigua", Zephyrus, 57 (2004). O tema das cecas galaico-visigodas ten sido retomado máis recentemente, en meirande fondura, por Ruth Pliego VÁzQuez, "Gallaecia en tiempos del Reino Visigodo de Toledo: sus emisiones monetarias", en Francisco Cebreiro Ares (ed.), Introducción a la Historia Monetaria de Galicia (s. II a.C.-XVII d.C.), A Coruña, Labirinto de Paixóns, 2012, páxs. 65-104.

14 Martín Fernández Calo, "Plinio, o Parroquial Suevo, e a evolución estrutural do poder local galaico na Antigüidade”, Gallaecia, 34 (2015), páxs. 175-207. 
albiscando as liñas básicas da súa influencia entre as comunidades locais, da súa evolución con respecto ao período alto-imperial, e da súa permanencia durante o dominio suévico temperán ${ }^{15}$. Tamén a este comezo de milenio se adscribe un pulo sen precedentes da arqueoloxía tardo-antiga da Gallaecia ${ }^{16}$. Certamente, as institucións locais, tan afastadas da materialidade das intervencións arqueolóxicas, non semellan un tema moi propicio para se nutrir dos aínda tímidos contributos desta disciplina, que pode proporcionar, iso si, uns lindeiros firmes nos que asentar a contextualización de toda pescuda institucionalista sobre as bases estruturais deste período.

Temos, pois, dentro dun panorama xeral de moi acentuado estancamento historiográfico, certas achegas isoladas que se teñen ocupado do poder local e aberto novas perspectivas que poderemos afondar dentro do noso reducido ámbito temático e cronolóxico: a identidade civil e as institucións representativas das comunidades galaicas tardo-antigas. Este obxecto de estudo, tan estritamente ancorado na comunidade local, demanda claramente - como teñen asentado as achegas das que vimos de facérmonos eco- unha vocación comprensiva entre épocas históricas adxacentes. Conforme veño insistindo dende a miña tese de licenciatura, o poder local foi o substrato de todo o artellamento político-administrativo da Gallaecia, principal supervivencia e nexo común que tiveron entre si os dominios romano, suevo e visigodo; e estes cos períodos castrexo e alto-medieval entre os que se insiren ${ }^{17}$. Evidentemente, unha atención exhaustiva e xeral ás interrelacións existentes entre todas estas épocas fica fóra das posibilidades dun estudo inevitabelmente parcial coma o presente, onde cómpre balizar, coma en toda investigación histórica, uns lindeiros cronolóxicos definidos. Mais resulta así natural formularmos a necesaria atención comprensiva entre os dominios suevo e visigodo, moi diferentes no que á súa historia e fontes propias se refire; pero entre os que o poder local, en concreto, conservou sen solución de continuidade - malia a certa cesura incidente no rexistro histórico — os trazos xerais da súa estrutura e, verémolo, das súas institucións.

\footnotetext{
15 Íd., "Transformacións e permanencia do municipium na Gallaecia baixo-romana", Cuadernos de Estudios Gallegos, LXIV, 130 (2017), páxs. 15-48.

${ }^{16}$ Así, nomeadamente, Jorge López Quiroga, El final de la Antigüedad en la Gallaecia: la transformación de las estructuras de poblamiento entre Miño y Duero (siglos V al X), A Coruña, Pedro Barrié de la Maza, 2004; Álvaro Rodríguez Resino, Do imperio romano á alta idade media: arqueoloxía da Tardoantigüidade en Galicia (séculos V-VIII), Noia, Toxosoutos, 2005; e, entroutros traballos seus, José Carlos Sánchez PARDo, "Sobre las bases económicas de las aristocracias en la Gallaecia suevo-visigoda (ca. 530-650 d.C.): comercio, minería y articulación fiscal", Anuario de Estudios Medievales, XLIV, 2 (2014), páxs. 983-1023.

${ }^{17}$ Martín Fernández Calo, A organización político-administrativa de Galicia na Antigüidade (séculos II a.C.-VIII d.C.), tese de licenciatura inédita (Universidade de Santiago de Compostela), páx. 182; na mesma liña, íd., Estado, poder e estruturas políticas na Gallaecia (séculos II a.C.-VIII d.C.), Santiago de Compostela, Blukk, 2018, páxs. 335-338.
} 


\section{Proposta DE ESTUdo}

Segundo a miña propia estimación, o Parroquial suevo reporta unhas 81 entidades políticas locais para a Gallaecia do século VI, e 117 para todo o reino suevo ${ }^{18}$. A citada fonte distingue tales entidades baixo os títulos ciuitas e pagus, segundo a ubicación urbana ou rural, respectivamente, das súas igrexas ${ }^{19}$. No período visigodo, a voz pagus, singularidade sueva, desaparece a prol de territorium, que designou, como souberon asentar P. Merêa e A. A. Girão, os distritos locais que demarcaran a Hispania daquel tempo, nexo entre os homónimos territoria medievais e as ciuitates romanas ${ }^{20}$, e — cómpre engadirmos-os pagi suevos. Escapan do noso coñecemento as mudanzas producidas logo da conquista visigoda sobre a estrutura territorial albiscada no Parroquial; mais dado o conservadorismo que caracterizou a organización imposta por Leovixildo na Gallaecia ${ }^{21}$, e sobre todo a sistemática correspondencia das cecas galaico-visigodas coas igrexas suevas $^{22}$, non semella que a mudanza tivese sido moi radical. Podemos manter, así, a sospeita dunha oitentena de comunidades locais no ámbito estrito da $G a$ llaecia tardo-antiga — grosso modo actuais Galiza e norte de Portugal—, e do cento longo no máis amplo do reino suevo, territorialidade galaica mantida, logo da conquista visigoda, ata mediados do século VII (Fig. 1) ${ }^{23}$.

É nesta constelación de comunidades locais, cuxa meirande parte non deixou máis información có seu simple nome consignado no Parroquial, onde propoño situar o foco do presente estudo. Tentaremos enxergar, globalmente, ao abeiro dos fragmentarios testemuños dos que dispomos, a dimensión da súa identidade civil, con especial interese na expresión máis transcendental da mesma: os seus órganos de representación popular.

Con todo, tal vocación de globalidade, e de facermos encaixar os fragmentos entre os que se esparexe o noso rexistro, non ha de ser confundida cun afán de xeneralización. Referinme antes á herdanza romana, onde a identidade e representación civís soan a aspectos consubstanciais e mesmo tópicos da organización política. Mais na Gallaecia tardo-antiga actuaron tamén outras herdanzas culturais, que confluíron sobre a constitución particular de cada comunidade local e condicionaron o desenvolvemento concreto das súas institucións. Nestas circunstancias,

\footnotetext{
18 Íd., "Plinio...", páx. 198.

19 Ibíd., páxs. 187-189.

${ }^{20}$ Paulo MerÊA e Aristides de Amorim GIRÃo, "Territórios portugueses do século XI", Revista Portuguesa de História, 2 (1943), páxs. 255-263; cfr. Fernández CALo, Estado..., páxs. 299-304.

${ }^{21}$ Pablo C. Díaz Martínez, "Gallaecia: de Reino Suevo a provincia visigoda", en Gerardo Pereira Menaut (coord.), Galicia fai dous mil anos: o feito diferencial Galego, vol. I, Santiago de Compostela, Museo do Pobo Galego, 1997, páxs. 253-278; LóPez CARreira, O reino..., páxs. 97-101; Fernández Calo, Estado..., páxs. 273 e segs.

22 Díaz Martínez, “Acuñación...”; R. Pliego VÁzquez, "Gallaecia...”.

${ }^{23}$ Cfr. Díaz Martínez, El reino..., páx. 249; Fernández Calo, Estado..., páxs. 314 e segs.
} 


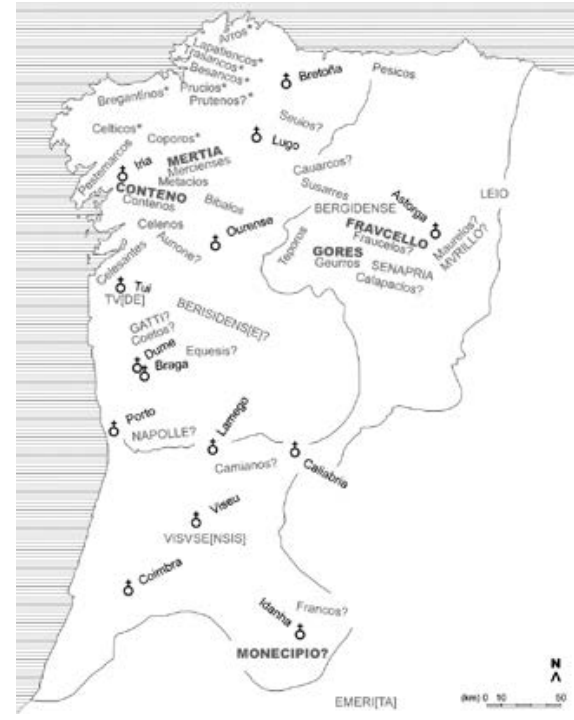

Figura 1. Mapa de referencia. A liña exterior delimita, dun xeito meramente aproximativo, a Gallaecia lato sensu na súa extensión sueva e visigoda temperá; a Gallaecia stricto sensu —en exclusión dos ámbitos asturicense e lusitano-, nos seus confíns tardo-visigodos, é delimitada pola liña interior. Sigo aquí a miña mesma cartografía reproducida en FERNÁNDEZ

CAlo, Estado..., páxs. 249, 297 e 318.

Salientadas con cruces, sés episcopais deste período. En gris e en minúscula, igrexas étnicas e comunidades afíns aludidas no texto: delibera-

damente, inclúense só as máis claramente asociábeis a esta categoría, co gallo de perfeccionarmos o contributo visual do mapa.

Con asterisco, igrexas mencionadas nas interpolacións irienses do Parroquial suevo.

Tamén en gris pero en maiúscula, cecas emisoras da serie Latina munita, e en negra as cecas visigodas citadas no texto e/ou reproducidas nas imaxes. Con interrogante e orientadas a cadanseu marco diocesano, entidades de incerta

localización. Nótese, nomeadamente, a concentración setentrional das igrexas étnicas, e a oriental da serie Latina. os trazos que poidamos albiscar dos corpos civís implicados e das súas instancias representativas non poderán ser xeneralizados a todo o período nin a todas as comunidades, senón ubicados provisoria e prudentemente no lugar que lles corresponde nesta escura etapa da nosa historia.

Como guión de traballo propoño así artellar o presente estudo a partires das diferentes herdanzas culturais que confluíron na nosa Tardoantigüidade. Por iso atenderei, en sucesivos apartados, ás formas de organización non cívica suxeridas polas "igrexas étnicas" do $\mathrm{Pa}$ rroquial suevo; á remanencia do réxime municipal romano a través, nomeadamente, da enigmática serie monetal Latina munita; e ao influxo do dereito xermánico, ao abeiro das fontes lexislativas visigodas e da súa senlleira institución do conuentus. O estudo pechará entón coa herdanza máis transversal, a eclesiástica, que co seu concepto da plebs Christiana xunguiu a diversidade xurídica e cultural posta de manifesto nos apartados anteriores. Nas conclusións, finalmente, proporei unhas valoracións xerais nas que se sintetizarán os resultados positivos do estudo e as tarefas pendentes que con el se albiscan para futuras investigacións.

\section{O PARROQUial SUEVO E AS IGREXAS ÉTNICAS}

A dimensión comunitaria do poder local atopa na nosa Tardoantigüidade a súa expresión máis evidente, pero tamén — fronte aos intereses xerais do presente estudo-menos "civil”, nas "igrexas étnicas” do Parroquial suevo. Caracterízanse 
estas pola denominación, canda menos en orixe, a partires non do topónimo do seu lugar de asentamento, como xeralmente acontece no Parroquial, senón en función do conxunto humano ao que representaban; derivando así, morfoloxicamente, dun acusativo masculino plural latino. É por iso que a cotío se teñen interpretado como unha proba da remanencia dunha organización social de carácter non civil, senón "tribal" ou "xentilicio" e mesmo pre-romano ${ }^{24}$.

Algunhas destas igrexas, en efecto, repiten etnónimos constatados dende a Idade do Ferro: Bibalos, Cauarcos, Celenos, Geurros, Pesicos, Pestemarcos e Teporos; evidencia que incrementa o numerario visigodo coa ceca Susarres ${ }^{25}$. A igrexa bracarense Equesis, malia a súa morfoloxía discordante, tamén se adoita incluír neste cómputo pola súa correspondencia co pobo castrexo dos Equaesi ${ }^{26}$. Seuios e Francos, pola súa banda, poderían entrar singularizadamente no cómputo de igrexas "étnicas" polo seu aparente etnónimo non pre-latino, senón xermánico ${ }^{27}$. Porén, noutros dez casos a denominación aparentemente etnonímica non pode ser confrontada con entidades étnicas recoñecíbeis por fontes complementarias ${ }^{28}$. As interpolacións irienses do Parroquial, pola súa banda, engaden ata nove igrexas étnicas máis ${ }^{29}$. Delas, Bregantinos e Lapatiencos constitúen xentilicios derivados de entidades testemuñadas só como topónimos en época romana: respectivamente, a cidade de Flauium Brigantium e o fito marítimo Lapatía kốrou ${ }^{30}$; embora o recentemente falecido L. Monteagudo asociase no seu momento este último á mención equívoca do xenitivo plural latino dun verdadeiro etnónimo, Lapatiancorum $^{31}$. Por outra banda, A. de Almeida Fernandes analizou as igrexas con ter-

\footnotetext{
${ }^{24}$ Así, David, Études..., páx. 81; Fernando López Alsina, La ciudad de Santiago de Compostela en la Alta Edad Media, Santiago de Compostela, Ayuntamiento de Santiago de Compostela, 1988, páx. 155; Amancio Isla FreZ, La sociedad gallega en la Alta Edad Media, Madrid, CSIC, 1992, páxs. 10 e segs.; A. de Almeida Fernandes, Paróquias suevas e dioceses visigóticas, Tarouca, 1997, páx. 21; DíAz Martínez, "Gallaecia, de reino...”, páx. 266; íd., "El Parrochiale...”, páx. 44. Téñase presente a enorme controversia que arrodea en Antropoloxía aos conceptos mencionados: cfr. Francisco BeLTRÁn LlORIS, "Un espejismo historiográfico: las organizaciones gentilicias hispanas", en Gerardo Pereira Menaut (dir.), Actas del primer congreso peninsular de Historia Antigua, vol. II, Santiago de Compostela, Universidade de Santiago de Compostela, 1988, páxs. 197-234, contra a súa aplicación mesmo na precedente época romana.

${ }^{25}$ Parochiale Suevum, IX, 4-6; X, 10; XI, 5 e 8; cfr., alén das fontes epigráficas locais, Pomponio Mela, Chorographia, III, 7-9; Plinio o vello, Naturalis Historia, III, 28 e IV, 111.

${ }^{26}$ Par., I, 17; cfr. Plin., Nat., III, 28 e CIL II, 2477.

27 Par., VII, 3; VIII, 3. Seuios, con todo, ten sido considerada unha mención equívoca de Lemos, polo que podería entrar tamén no cómputo de etnónimos antigos: cfr. SÁNCHEZ PARDO, "Organización eclesiástica y social en la Galicia tardoantigua: una perspectiva geográfico-arqueológica del Parroquial Suevo", Hispania Sacra, LXVI, 134 (2014), páx. 445.

${ }^{28}$ Par., I, 3; III, 6; IX, 9 e 11; X, 7 e 9; XI, 6-7; XI, 4; XII, 10.

29 Ibíd., XI, 8 (interpolación). Arredor da problemática específica e datación destas interpolacións, véxanse David, Études..., páx. 42, nota xi, 8; SÁnchez Pardo, “Organización...”, páx. 457-458; FernándeZ CALO, "Plinio...", páx. 192-193.

${ }^{30}$ Par, XI, 8 (interpolación); Claudio Ptolomeo, Geōgraphikèe, II, 6, 4.

31 Luis Monteagudo, "Carta de Coruña romana (iii): costa”, Emerita, 25 (1957), páxs. 64-72, citado en Alain Tranoy, La Galice romaine: recherches sur le nord-ouest de la péninsule ibérique dans l'Antiquité,
} 


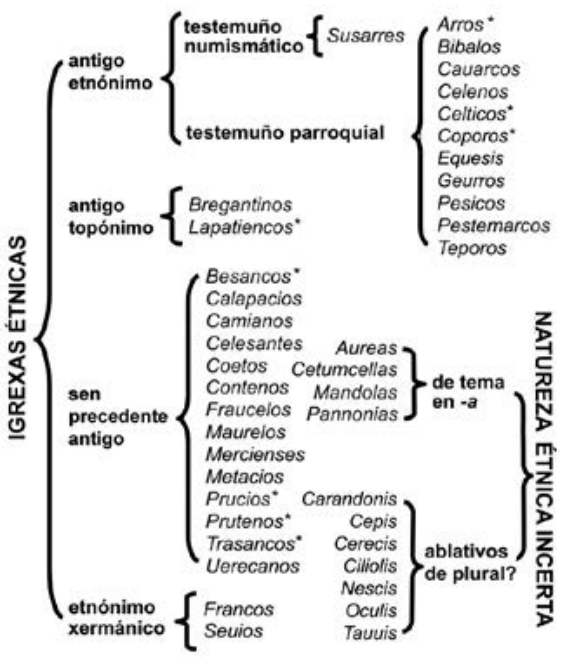

Figura 2. Igrexas étnicas constatadas.

Diagrama do conxunto destas entidades aludidas no texto, clasificadas segundo o grao de certeza da súa inclusión na categoría e da morfoloxía, adscrición étnica e/ou precedentes do seu testemuño. Con asterisco, as mencionadas por interpolacións do Parroquial suevo. minación en -is - coma Equesiscomo ablativos plurais, suxeríndolles un contido étnico que sumaría outras sete $^{32}$. Tamén Aureas, Cetumcellas, Mandolas e Pannonias se poderían engadir a esta categoría, no caso de procederen dun tema masculino en $-a^{33}$.

Todas estas igrexas, como vemos de diversa, incerta e eventualmente desbotábel relación con comunidades de organización non civil, teñen resultado adscritas con meirande ou menor insistencia ao repertorio de "igrexas étnicas" da Gallaecia sueva (Fig. 2).

Con todo, este paradigma interpretativo, case consensual e mesmo tópico na nosa historiografía, ten sufrido algunha crítica dende que o asentara o padre P. David. En efecto, J. C. Rivas Quintas e J. C. Sánchez Pardo teñen formulado ultimamente que a organización destas igrexas non tería por qué diferir substancialmente das súas homólogas de denominación tópica ${ }^{34}$. A súa herdanza actual semella apoiar esta postura, ao reproduciren, por exemplo, os arciprestados composteláns de Bezoucos, Céltigos, Posmarcos ou Pruzos a mesma denominación primitiva sen que isto implique ningunha exclusividade da súa organización eclesial

\footnotetext{
Paris, Diffusion de Boccard, 1981, páx. 55, nota 141. O certo é que tamén Bregantinos se quixo postular no seu momento como entidade étnica ou fracción xentilicia dos ártabros: véxase, por exemplo, Florentino López Cuevillas, La civilización céltica en Galicia, Santiago de Compostela, Porto y Cia, 1953, páx. 51. Con todo, antes da interpolación do Parroquial suevo non contamos con ningunha referencia dos Bregantinos na súa dimensión étnica, limitándose sen exepción as fontes clásicas a identificaren Brigantium ou Brigantia como topónimo: Ptol., Geog., II, 6, 4; Dión Casio, Historia Romana, XXXVII, 53; Itinerarium Antonini, 424, 5; Notitia dignitatum, pars Occidentalis, XLII, 30; Paulo Orosio, Historia adversus paganos, I, 2 , 71-72. Polo demais, boa parte da historiografía actual matiza a existencia mesma de fraccións xentilicias no seo das antigas ciuitates galaicas: cfr. Gerardo Pereira Menaut, "Los castella y las comunidades de Gallaecia”, Zephyrus, 34-35 (1982), páxs. 245-268; Beltrán Lloris, "Un espejismo...”; Fernández Calo, Estado..., páx. 47. Cómpre sinalarmos, de calquera xeito, que a existencia ou non duns Bregantinos pre-romanos non altera en absoluto a premisa do reforzamento tardo-antigo das estruturas étnicas desta comunidade, pois do que non hai dúbida é da súa constitución civil en época romana.

${ }^{32}$ Fernandes, Paróquias suevas..., páx. 21; igrexas implicadas: Par., I, 7; 10-11; 14-15; II, $10 ; 23$.

33 Par., I, 2; II, 24; XII, 5; I, 19.

34 Juan Carlos Rivas Fernández, Antigüedad del episcopado auriense, Ourense, Duen de Bux, 2003, páxs. 126 e 265; SÁnchez PARdo, “Organización...”, páxs. 461-464.
} 
nin social verbo ao resto da diocese, senón simplemente a súa relación con parroquias que fosilizaron nos seus topónimos os etnónimos orixinais. $\mathrm{O}$ mesmo se podería sospeitar para a Tardoantigüidade, cando estas igrexas, independentemente da súa denominación, puideron funcionar exactamente igual cás restantes... Con todo, fronte ao dito, o contexto histórico da nosa Tardoantigüidade amosa que non hai lugar para a recusación absoluta do paradigma étnico, senón, se acaso, para o seu afinamento.

No século V, en efecto, o colapso das estruturas imperiais da Gallaecia traduciuse na independencia fáctica de moitas comunidades locais, segundo ilustran cidades de tan vella tradición romana coma Braga, Chaves ou Lugo antes de sufriren as acometidas bárbaras ${ }^{35}$, pero tamén comunidades de denominación “étnica" coma os Auregenses ou os Aunonenses ${ }^{36}$. Esta última constátase co título plebs, suxeito a unha semántica indubidosamente romano-cristiá, sobre a que voltaremos máis adiante; pero da que cómpre adiantarmos que non discriminaría a súa constitución municipal ${ }^{37}$. Semella a todas luces factíbel, pois, que a plebs Aunonensis derivase dun municipium baixo-romano homónimo; mais se cadra resulte tamén reveladora a súa mención étnica e non tópica no Cronicón de Hidacio de Chaves, cando o insigne limiao aludira ás principais comunidades urbanas do seu tempo — pero tamén a outras secundarias ${ }^{38}$ — preferentemente pola simple mención do seu topónimo. Embora nada obste que no século V a plebs Aunonensis conservase aínda parte da súa identidade municipal, as circunstancias políticas daquel tempo houberon de motivaren axiña mudanzas que canda menos a desdebuxaron. Nunha comunidade rural, como é o caso, isto puido motivar o desenvolvemento de formas de solidariedade familiar e de clientelaxe ao abeiro das institucións sociais romanas ou das autóctonas remanentes. Nas mencións étnicas de Hidacio podemos estar perante municipia de feble entidade urbana; mais uns municipia, no seu contexto de confrontación cos suevos e de inexistencia dunha potestade estatal unificada, inmersos tamén nunha transición deica novas formas de organización socio-política de carácter non civil. Así entenderemos que o Parroquial convertese en etnónimos certas entidades urbanas de época romana, como ilustra sobre todo, polo seu epíteto imperial, Brigantium Flauium: non só unha transición gramatical, senón tamén socio-política, semella denotarse da súa nova denominación parroquial Bregantinos. No caso dos Aunonenses esta transición sería curtada axiña, se cadra co seu sometemento pactado aos suevos ${ }^{39}$; de xeito que no Parroquial a comunidade vai aparecer xa mencionada como unha

\footnotetext{
35 Respectivamente, Hidacio de Chaves, Chronicon, 174 [167], 196 [191] e 199 [194].

36 Ibíd., 197 [202], 233 [229] e 239 [235].

37 Fernández CALO, "Transformacións...”, páxs. 41-42.

38 Como ilustra o municipium Lais: Hyd., Chron., 253 [247].

39 Ibíd., 239 [235].
} 
igrexa tópica - de feito como un pagus-: Aunone ${ }^{40}$. Nas igrexas étnicas, porén, este hiato houbo de ser ben máis longo.

Certas tendencias estruturais de meirande envergadura histórica e xeográfica poden apoiar esta lectura. O proceso de reocupación castrexa ao que se asiste na Gallaecia dende o século III insírese dende logo no contexto de dominación imperial e na estrutura económica do fundus romano ${ }^{41}$, mais comporta a todas luces a revitalización duns patróns culturais autóctonos longamente arrecantados, que non desaparecidos, na Alta Romanidade ${ }^{42}$. Todo o Occidente baixo-romano foi partícipe deste serodio rexurdimento das culturas autóctonas, expresadas en múltiples canles, coma a arte, a relixiosidade pagá e os patróns de asentamento ${ }^{43}$, nun proceso que non fixo senón reforzarse co esmorecemento do Imperio, nomeadamente nas provincias nas que este non foi suplantado axiña por unha potestade estatal estábel. Na Gran Bretaña e na Mauritania post-romanas moitas das comunidades locais se redefiniron baixo a súa tradición cultural indíxena, subxacente baixo o período romano, allea tanto ao réxime civil imperial como, eventualmente, ao cristianismo ${ }^{44}$. Se cadra boa parte da Gallaecia, onde os suevos non semellan ter consolidado as súas estruturas estatais antes da segunda metade do século $\mathrm{VI}^{45}$, resulte máis paralelizábel a estes exemplos do que a outros reinos xermánicos de artellamento daquela máis firme, coma o franco, o visigodo ou o ostrogodo.

Certamente, canda menos os Aunonenses semellan ter posuído xa unha identidade cristiá no século $\mathrm{V}$, a xulgarmos das notábeis implicacións ideolóxicas do título plebs que lles asignou Hidacio ${ }^{46}$. Mais non é menos certo que a cristianización da Gallaecia era daquela aínda superficial, culminando só a todas luces baixo o maxisterio de Martiño dumiense, en plena época suevo-católica: o seu sermón

\footnotetext{
40 Par, XII, 12.

${ }^{41}$ Cfr. Felipe Arias Vilas, “Apuntes sobre a ocupación do territorio na Galicia Baixorromana: castros e vilas", en Galicia da romanidade á xermanización: problemas históricos e culturais, Santiago de Compostela, Museo do Pobo Galego, 1993, páxs. 201-208; Fernández CALO, “Transformacións...”, cit., páxs. 30-31.

42 Fernández Calo, "Transformacións...”, páx. 30.

${ }^{43}$ Respectivamente verbo ás cuestións enunciadas, cfr. Ramsay MacMullen, "The Celtic Renaissance", en MacMullen, Changes in the Roman Empire: Changes in the Ordinary, Princeton, Princeton University Press, 1990, páxs. 41-48; Aline Rousselle, Croire et guérir: la foi en Gaule dans l'Antiquité tardive, Paris, Fayard, 1990; Tranoy, La Galice..., páxs. 419-422.

${ }^{44}$ Cfr. respectivamente Chris Wickham, Framing the Early Middle Ages: Europe and the Mediterranean (400-800), Oxford, Oxford University Press, 2005, páxs. 303 e segs.; Gabriel CAMPs, "Rex gentium Maurorum et Romanorum: recherches sur les royaumes de Maurétanie des VI ${ }^{\mathrm{e}}$ au VII ${ }^{\mathrm{e}}$ siècles", Antiquités Africaines, 20 (1984), páxs. 183-218.

45 Purificación Ubric Rabaneda, La Iglesia y los Estados bárbaros en la Hispania del siglo V (409-507), tese de doutoramento inédita, Universidad de Granada, 2003, páxs. 108 e segs.; Óscar NúÑEz GARCíA, Un novo deus para os galaicos: a cristianización de Gallaecia, Santiago de Compostela, Lóstrego, 2012, páx. 78; Fernández Calo, Estado..., páx. 212.

${ }^{46}$ Cfr. Fernández Calo, "Transformacións...”, páx. 39.
} 
De correctione rusticorum e o mesmo Parroquial denotan paralelamente, en pleno século VI, a máis primitiva implantación eclesiástica sobre boa parte do ager galaico. Porén, na faixa cantábrica da península ibérica este proceso foi aínda máis serodio ${ }^{47}$, e certamente non semella posíbel establecermos un límite taxativo entre esta rexión de pertinaz paganismo e a veciña Gallaecia cristiá.

Neste contexto de independencia fáctica, retracción civil e persistencia do paganismo, moitas bisbarras periféricas — setentrionais e/ou montañosas - só resultaron integradas política e eclesiasticamente nas estruturas do Reino a mediados do século VI. Isto explicaría que as igrexas fundadas no seu seo recibisen non o topónimo do seu asento primitivo — que non existira ata o daquela—, senón o nome mesmo das comunidades, de particular artellamento étnico, ás que pretendían representar (Fig. 1).

Ademais, recorrendo outra volta ao paralelo británico, antes do apostolado de Agostiño de Canterbury entre os anglo-saxóns ${ }^{48}$, a organización eclesial "céltica" ou "insular" das comunidades bretoas e irlandesas fundamentárase na potestade persoal fronte á territorial romana ${ }^{49}$. $\mathrm{Na}$ Gallaecia, Bretoña, a máis afastada igrexa da diáspora bretoa, mantivo en pleno século VI a súa organización de carácter persoa $^{50}$, que puido ter influído decisivamente na evanxelización e eventual artellamento eclesiástico das últimas comunidades pagás da nosa terra, e nomeadamente nas igrexas étnicas do Parroquial. En fin, só a cristianización destas comunidades e o artellamento territorial da Igrexa galaica, promovido este nos dous concilios de Braga ${ }^{51}$, antes da redación do Parroquial, diluirían por fin a súa singularidade étnica.

Coido que tales consideracións poden afinar o noso recoñecemento da historia primitiva destas igrexas, conciliando as posturas encontradas arredor do seu carácter étnico. Cómpre matizarmos, en efecto, as implicacións potenciais desta premisa no tempo no que as igrexas en cuestión foron consignadas no Parroquial, a prol de avalarmos a fugaz retracción, entre os séculos V e VI —o "século escuro suevo"-, das estruturas civís nas áreas periféricas da Gallaecia das que formaban parte, antes da consolidación política e eclesial suevo-católica que revertería fi-

\footnotetext{
${ }^{47}$ Marcelo VIGIL, "Romanización y permanencia de estructuras sociales indígenas en la España septentrional", en Conflictos y estructuras sociales en la Hispania Antigua, Madrid, Akal, 1977, páxs. 129-137. 48 Arredor deste proceso, véxase Barbara Yorke, The Conversion of Britain: Religion, Politics and Society in Britain, c.600-800, London-New York, Routledge, 2014. Eu mesmo teño revisitado recentemente o temperán ordenamento eclesiástico da Gran Bretaña nesta mesma revista: Martín Fernández CALO, "Os synodi suevo-católicos: implicacións político-administrativas dunha bipartición metropolitana", Cuadernos de Estudios Gallegos, LXIII, 129 (2016), páxs. 143-145.

49 Para unha síntese crítica recente, e en galego, desta cuestión, véxase Simon Young, Bretoña: camiños novos, Noia, Toxosoutos, 2002, páxs. 36-40.

${ }^{50}$ Cfr. David, Recherches..., páxs. 71-72; Young, Bretoña..., páxs. 107-111; Fernández Calo, Estado..., páxs. 246-247.

${ }^{51}$ Conc. Bracarensis I, 6, 8 e 19; II, praef.; capitula Martini, 1-2; 4; 6-7; 15-16; 18.
} 
nalmente este proceso. As cecas visigodas de Conteno, Fraucello e Mertia ${ }^{52}$, correspondentes a cadansúa igrexa étnica, evidencian que tamén esta inflexión puido ter, canda menos puntualmente, o seu nidio reflexo toponímico (Fig. 1).

\section{A SERIE LATINA E A SUPERVIVENCIA MUNICIPAL}

Fronte ás igrexas étnicas, o artellamento civil das comunidades da Gallaecia semella a norma da nosa Tardoantigüidade. Sen saírmos das herdanzas culturais, neste punto non atopamos meramente o serodio rexurdimento de formas de organización étnica longo tempo arrecantadas, senón a remanencia dun réxime constitucional ben coñecido, amplamente constatado entre as comunidades locais da Gallaecia, e cronoloxicamente vindeiro á época aquí estudada: o municipium romano. O común escepticismo historiográfico contra a difusión deste réxime organizativo na Gallaecia, polo carácter rural da rexión e a pobreza da súa epigrafía honorífica ${ }^{53}$, podería relativizar a súa potencial influencia na nosa Tardoantigüidade. Porén, o rexistro baixo-romano, comunmente soslaiado, desautoriza semellante pesimismo: o meu recente estudo ao respecto ten refrendado, coido que con algunha firmeza, a plena operatividade do municipium galaico-romano entre os séculos III e $\mathrm{V}^{54}$; e isto outórganos un punto de partida ineludíbel co que encetarmos a cuestión da súa supervivencia posterior.

Neste punto, conectando o século V co VI e confundíndose co proceso de consolidación sueva na Gallaecia, emerxe o máis significativo, e amplamente eludido como tal, indicio da remanencia tardo-antiga do municipium galaico: a serie numismática Latina munita (Fig. 3). Así designada pola fórmula epigráfica Latina e derivadas, non sempre presentes, a serie caracterízase tamén polo seu valor tremís, a súa homoxénea metroloxía, e a presenza dun busto anónimo no anverso e un característico motivo cruciforme no reverso ${ }^{55}$. Débese a D. M. Metcalf a interpretación de meirande predicamento desta serie ${ }^{56}$, que denominarei aquí

\footnotetext{
${ }^{52}$ Catalogadas por Ruth Pliego VÁzquez, La moneda visigoda, vol. I, Sevilla, Universidad de Sevilla, 2009, páxs. 141-143. Máis adiante reproduciremos Mertia como exemplo de emisión galaico-visigoda (Fig. 4).

${ }^{23}$ Véxanse, por exemplo, Tranoy, La Galice..., cit., páx. 205; Pereira Menaut, "Los castella...", páxs. 263-265; Patrick Le Roux, "Las ciudades de la Callaecia romana durante el Alto Imperio", Gerión, 14 (1996), páx. 368; Ana María SuÁrez PiÑeIro, A romanización en Galicia, Noia, Toxosoutos, 2009, páx. 64.

54 FERnández CAlo, "Transformacións...".

${ }^{55}$ Cfr. João M. Peixoto Cabral e David Michael Metcalf, A moeda sueva: Suevic Coinage, Porto, Sociedade Portuguesa de Numismática, 1997, páxs. 117 e segs.; Antonio Roma Valdés, "Emisiones monetarias del siglo VI d.C. con leyenda LATINA MVNITA: estado del debate", Brigecio, 12 (2002), páxs. 79-80.

${ }^{56}$ Para un encadramento historiográfico en fondura, véxase Francisco Cebreiro Ares, "Dificultades que plantea el estudio de la historia monetaria sueva", en Francisco Cebreiro Ares (ed.), Introducción a la Historia Monetaria de Galicia (s. II a.C.-XVII d.C.), A Coruña, Labirinto de Paixóns, 2012, páxs. 31-63; e sobre todo Pablo NúÑEz Meneses, Historia monetaria de la Galicia medieval, tese de doutoramento inédita, Universidade de Santiago de Compostela, 2017, páxs. 126-130.
} 
"monárquica" por atribuír o numísmata británico o calificativo Latina á vontade integradora da monarquía - xermánica - verbo ao corpo social maioritario - latino - no seu contexto de consolidación estatal logo da década do $560^{57}$. Porén, nin os lugares de emisión nin a cronoloxía potencial semellan apoiar esta hipótese. O rango de datación tense revelado ben máis amplo e incerto ${ }^{58}$; e as cecas asturicenses, únicas asociábeis á consolidación das fronteiras suevas, son só un ámbito significativo da súa área de distribución, cuxo grande fulcro foi en realidade Mérida ${ }^{59}$, cidade sen dúbida sueva a mediados do século $\mathrm{V}$, pero xa visigoda no $\mathrm{VI}^{60}$. Finalmente, e contravindo as convencións previsíbeis da numismática tardo-antiga, na serie Latina non hai rastro de monarca ningún, nin suevo nin doutra nacionalidade ${ }^{61}$.

Nestas circunstancias, albíscanse motivos máis ca razoábeis para dubidarmos da idoneidade desta hipótese. En primeiro lugar, a suposta énfase nunha "latinidade" cultural podería lerse dende
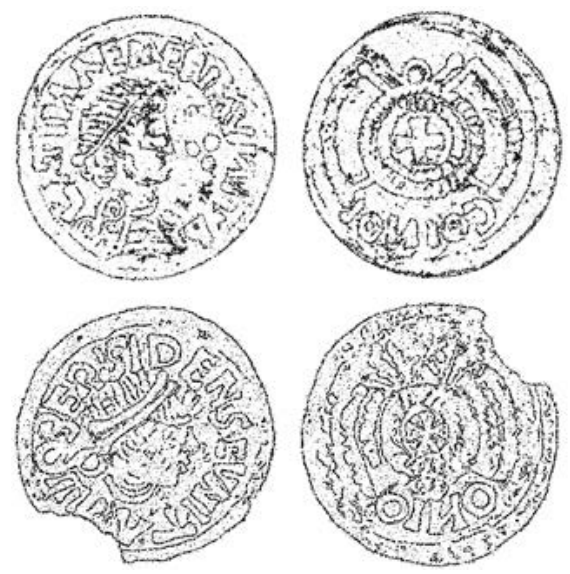

Figura 3. Exemplares da serie Latina. Imaxe superior: emisión emeritense. Anverso: LATINA EMERI MVNITA; reverso: COINOI (retrógrado). Imaxe inferior: emisión da ceca Berese. Anverso: BERISIDENSCVNITA; reverso: ONIO (retrógrado). Elaboración propia en base ás fotografías de GonzÁlez GARcía e Martínez Chico, "Hallazgo...”, páx. 226, e Cabral e Metcalf, A moeda..., páx. 305, reproducida por MARTín VISO, "Circuits of

Power...”, páx. 224. Nótese, nomeadamente, a elusión de toda referencia rexia en ambas as moedas, amais da súa afinidade iconográfica, que xustifica a inclusión da inferior, malia a súa carencia da definitoria fórmula Latina, na mesma serie monetal. unha perspectiva xustamente contraria: no canto dunha mensaxe integradora da monarquía xermánica, ausente nestas moedas, unha afirmación identitaria e mesmo excluínte do corpo social latino maioritario. Segundo algúns estudosos, a serie Latina certificaría a plena autonomía das comunidades emisoras, representadas nin máis nin menos que polos descen-

\footnotetext{
57 David Michael Metcalf, "The coinage of the first and second Suevic kingdoms: from romanitas to latinization", en Galicia da romanidade á xermanización: problemas históricos e culturais, Santiago de Compostela, Museo do Pobo Galego, 1993, páx. 362.

58 Cfr. Roma Valdés, "Emisiones...", páx. 82.

59 Como teñen asentado definitivamente Alberto GonzÁlez García e David Martínez Chico, "Hallazgo de un triente emeritense de la serie LATINA MVNITA en Cáceres (España)", Gallaecia, 25 (2016), páxs. 283-298.

${ }^{60}$ Cfr. Díaz Martínez, El reino..., páxs. 119 e 130-131; Fernández Calo, Estado..., páxs. 216-217.

${ }^{61}$ Roma Valdés, "Emisiones...”, páx. 84.
} 
dentes das elites romanas ${ }^{62}$. Mais esta mesma lectura social atopa unhas nidias implicacións institucionais que xa teñen sido explotadas por outros investigadores. En efecto - e con isto entramos por fin en materia-, M. G. Marques, J. C. Ribeiro e L.A. García Moreno teñen reparado paralelamente na posíbel evocación municipal da serie: este suxerindo a regalía de emisión do poder episcopal galaico; aqueles, máis significativamente para a noción da supervivencia municipal, o desempeño de maxistrados monetais ${ }^{63}$. Para os portugueses, en efecto, certas mencións en xenitivo de aspecto antroponímico que ocasionalmente xalonan estes numismas, entre os que os máis claros son Eli, Iacottis, Iuli e Talassi, aludirían non á toponimia das cecas senón á onomástica dos maxistrados encargados da emisión monetal ${ }^{64}$.

Recentemente, A. González García e D. Martínez Chico teñen achegado unha tentativa de conciliación entre os contraditorios paradigmas que vimos de sintetizar, argumentando que, supostamente, a figura do comes ciuitatis xunguiría ambos os aspectos, municipal e monárquico, do goberno local ${ }^{65}$. Porén, tal suxerencia semella poder desbotarse a xulgar polo directo nomeamento rexio, non curial nin popular, dos comites; quen ademais, en caso de se responsabilizaren da emisión de moeda, dificilmente poderían depender da lei municipal antes ca da rexia. Non semella haber lugar, abofé, para conciliación ningunha entrambos os paradigmas, ou canda menos non ao abeiro do comitatus.

Nestas circunstancias, a "latinidade" non semella ter nunha moeda mellor acepción cá xurídica, que no noso caso evocaría a constitución das entidades emisoras como municipia Latina. O dereito latino foi en efecto o réxime xurídico que regulamentara a vida cidadá das comunidades hispanas dende a década do 70 d.C., condicionando dende aquela a súa constitución municipal. Neste senso, para os municipia galaicos, como para os do resto da península ibérica, a Latinitas non evocou outra cousa cá súa lei constitutiva. Na Gallaecia romana non temos certamente constancia de emisións municipais ${ }^{66}$, pero esta foi de certo unha po-

\footnotetext{
${ }^{62}$ Nomeadamente entre as achegas recentes, Iñaki MARTín VISO, "Circuits of Power in a Fragmented Space: Gold Coinage in the Meseta del Duero (Sixth-Seventh Centuries", en Julio Escalona e Andrew Reynolds (eds.), Scale and scale change in the Early Middle Ages: Exploring landscape, local society and the world beyond, Tunhout, Brepols, 2011, páx. 227; NúÑEz MENESES, Historia monetaria..., páx. 127.

${ }^{63}$ Mário Gomes Marques e José Cardim Riberro, "As legendas da série Latina Munita", en IV Congresso Nacional de Numismática, Lisboa, 1998; Luis A. García Moreno, "La Iglesia y el cristianismo en la Galecia de época sueva", Antigüedad y Cristianismo, 23 (2006), páxs. 46-47. Fanse eco da tese municipal Philip Grierson e Mark Blackburn, Medieval European Coinage, vol. I, Cambridge, Cambridge University Press, 2006, páxs. 79-80.

${ }^{64}$ José Cardim Ribeiro, "Da existência de nomes pessoais em legendas de tremisses da série Latina munita", en Mário Gomes Marques, A moeda peninsular na idade das trevas, Sintra, Instituto de Sintra, 1998, páxs. 173-185, aludindo ademais a Emeri, neste caso máis plausibelmente adscribíbel á abreviatura de Emerita, Mérida.

${ }^{65}$ GonZález García e Martínez Chico, "Hallazgo....", páx. 227.

${ }^{66}$ Cfr. María Milagros Cavada Nieto, "Monedas romanas de ceca hispana halladas en Galicia", Gallaecia, 13 (1992), páxs. 97-111.
} 
tencialidade contemplada pola propia constitución dos seus municipia. Se no século VI atopamos unha serie monetal expresamente adxectivada Latina, emitida por unhas comunidades que - como avanzamos antes - ata o século anterior mantiveran o seu funcionamento municipal, cómpre admitir definitivamente que o fixeron co gallo de evocaren este vello dereito. Atopamos así un indicio excepcional da vixencia do municipium romano entre estas comunidades no século VI.

As únicas cecas da serie que proporcionan unha lectura inequívoca ubícanse na fronteira suevo-visigoda: Bergidum, Emerita, Leio, Murillo e Senapria ${ }^{67}$; ou sexa, o Bierzo, Mérida, León, algunha das igrexas de incerta localización que o Parroquial consigna como Maurelos $^{68}$, e Sanabria, todas elas adscribíbeis, dun xeito máis ou menos claro, ao ámbito asturicense. Porén, o cómputo potencial é moito máis amplo e inclúe posíbeis cecas no mesmo fulcro galaico do reino suevo (Fig. 1).

Servíndonos sempre do catálogo de A. Roma Valdés ${ }^{69}$, atopamos o exemplo máis significativo na lenda BERISIDENSCVNITA, presente nun numisma asociado á serie pola súa tipoloxía formal, malia a ausencia da súa definitoria fórmula Latina (Fig. 3). Esta lenda semella referenciar unha ceca Berisidensis, ou sexa, correspondente á igrexa bracarense Berese, de incerta redución xeográfica ${ }^{70}$. A cotío, con todo, se a ten identificado co Bierzo ${ }^{71}$, o que ao meu ver discrepa coa forma BERGIDENSEMVNITA que aparece nas emisións seguras desta bisbarra ${ }^{72}$. Coido, pois, que o máis sensato é disociarmos ambas as lendas, postulando a súa relación con dúas cecas diferentes: Berese e Bergidum. Alén disto, a lenda LATINAMVNETANTV semella conter unha referencia abreviada á ceca Tudensis, Tui. A hipótese dunha abreviación non no nome da ceca, senón no adxectivo Latina, podería vencellar á igrexa portucalense $\mathrm{Napoli}^{73}$ a lenda LATINAPOLLE. Pola súa banda, nunha das lendas que M. G. Marques e J. C. Ribeiro quixeron ler en clave antroponímica, LATINAGATTIMVN, podería haber tamén unha referencia á igrexa bracarense $\operatorname{Coetos}^{74}$, por presentar esta as lecturas alternativas -e menos sistemáticas- de Gotis e Gotthis na tradición manuscrita do Parroquial suevo $^{75}$. E finalmente, pasando ás terras lusitanas do Reino, L. A. García Moreno

\footnotetext{
${ }^{67}$ No que converxerían Roma Valdés, “Emisiones...”, páx. 84 e García Moreno, "La Iglesia...”, páxs. 46-47.

68 Par, X, 7.

69 Roma Valdés, “Emisiones...”, páxs. 81-82.

70 Par., I, 23; cfr. García Moreno, “La Iglesia...”, páx. 47, nota 43.

${ }^{71}$ Por exemplo, Mário Gomes Marques, A moeda peninsular na idade das trevas, Sintra, Instituto de Sintra, 1998, páx. 165; MarTín Viso, "Circuits of Power...”, páx. 223.

72 Cfr. Roma Valdés, “Emisiones...”, páxs. 81.

73 Par, II, 11.

74 Ibíd., I, 3.

${ }^{75}$ Cfr. DAvid, Études..., páx. 32, nota i, 3.
} 
ten querido ver a referencia a unha ceca Uisusensis - Viseu? - na lenda LMENIVISVSEVVTII ${ }^{76}$.

Non pretendo incrementar artificialmente a representación galaica da serie Latina, e de feito hei de sinalar que as aludidas mencións a Coetos e Napoli, igrexas in uicino, non semellan acaídas para o asento de cecas por mor da súa ubicación na xurisdición local de cadansúa cidade episcopal, canda menos segundo a miña propia hipótese interpretativa da terminoloxía do Parroquial suevo, da que me fixen eco para a estimación numérica das comunidades locais da Gallaecia deste tempo ${ }^{77}$. Ao meu ver, alén das cecas asturicenses antes aludidas, as únicas plausíbeis ubicadas no ámbito estrito da Gallaecia son as que xa ten salientado L. A. García Moreno: Berisidensis e Tudensis ${ }^{78}$.

Dúas cecas poden non parecer moito, pero resultan dunha importancia decisiva para avaliarmos o panorama político no que se inseriron as comunidades galaicas do século VI, tanto na área fulcral sueva coma na súa fronteira oriental. Sendo Mérida a protagonista cuantitativa da serie Latina, probabelmente cumpra atribuírlle a esta cidade a súa orixe primeira, dende a que se difundiría ás demais cecas. No caso das galaicas, onde nunca houbera emisións municipais, a serie Latina ten que ser asociada sen dúbida a este influxo externo: a adopción dunha tendencia política de procedencia asturicense ou lusitana, mais baixo o análogo requisito da persistente identidade xurídica do municipium galaico. A serie Latina enxerga pois o rico panorama institucional do noso século VI, no que o municipium mantiña unha certa influencia nalgunhas comunidades locais, convivindo probabelmente con outras formas organizativas.

A conquista leovixildiana do 585 dá termo ao reino suevo e a algunhas — realmente moi poucas ${ }^{79}$ — das súas singularidades, entre as que figura a moeda, que pasa a se emitir en nome dos reis visigodos, ao abeiro, ata mediados do século VII, da meirande proliferación de cecas locais en toda a nosa Tardoantigüidade, e probabelmente en toda a nosa historia; pero á que non sobreviviu a serie Latina. As cecas galaico-visigodas terán unha nidia correspondencia cos territoria coetáneos, polo que seguirán a seren unha nidia expresión do poder local ${ }^{80}$. Porén, neste caso non hai indicios de implicación municipal ningunha: a homoxeneidade destas novas moedas, e nomea-

\footnotetext{
76 García Moreno, “La Iglesia...”, páx. 47, nota 43, optando pola lectura LMENIVISVSENTIZ.

77 Fernández Calo, "Plinio...”, páxs. 187-189.

78 Véxase a nota 76.

${ }^{79}$ Cfr. Díaz Martínez, “Gallaecia...”, páx. 265; íd., El reino..., páx. 249; Fernández Calo, Estado..., páxs. 273 e segs.

${ }^{80}$ Véxanse Díaz Martínez, “Acuñación...”; Pliego VÁzQuez, “Gallaecia...”, páx. 99; SÁnchez Pardo, "Sobre las bases...", páx. 1006; Barroso CABrera, et al., "Gallaecia...”, páxs. 110-114; FernándeZ CALO, Estado..., páxs. 283-287.
} 
damente a súa agora sempre clara alusión ao rei en curso $^{81}$, fan pensar na súa relación unívoca coa lexislación rexia pertinente, non con ningún antergo substrato xurídico latente nas comunidades emisoras (Fig. 4). De optarmos por unha das institucións locais deste período, as cecas galaico-visigodas semellan perante todo a expresión - agora si- da nova elite condal, de ampla autonomía e nidiamente ancorada na comunidade local ${ }^{82}$, pero de unívoca dependencia rexia e sen conexión posíbel coas maxistraturas colexiadas e temporais que definiran o réxime municipal e as súas competencias de emisión.

O que o dominio visigodo aporta á investigación institucionalista da Tardoantigüidade galaica, en materia municipal, son as súas amplas fontes lexislativas. Extrapolarmos as súas implicacións no entramado organizativo local da Gallaecia pode dar certa-
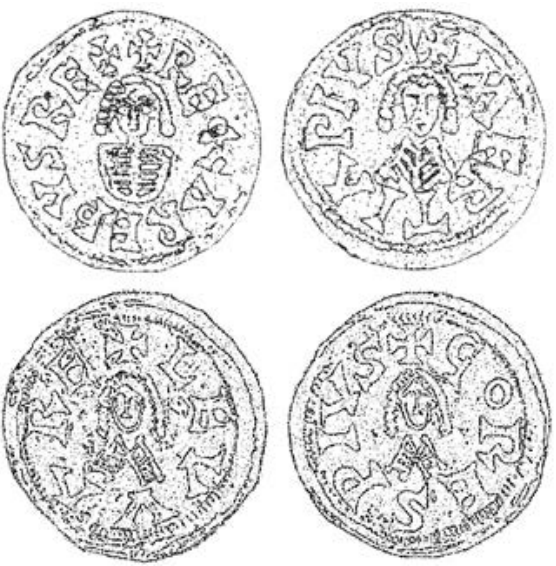

Figura 4. Exemplares de numerario galaico-visigodo. Imaxe superior: cuñaxe de Recaredo (586-601) en Merza. Anverso: † RECCAREPVS RE $\uparrow$; reverso: ' $\uparrow$ MERTIA PIVS. Imaxe inferior: cuñaxe de Liuva (601-603) en Valdeorras. Anverso: + LEVVA RE; reverso: ' + GORES PIVS. Elaboración propia en base ás fotografias de PLIEGo VÁzQUEZ, “Gallaecia...”, páxs. 82 e 84. Nótese, nomeadamente, a explícita referencia rexia destes exemplares, que os afasta da serie Latina (cfr. Fig. 3). mente a impresión dunha certa pervivencia das curias e doutras institucións municipais ${ }^{83}$, malia ter C. Sánchez-Albornoz, ao meu ver con máis teimosía ca razón, recusado hai tempo a validez destes testemuños ${ }^{84}$.

Porén, válidas ou non, o certo é que as esporádicas noticias en cuestión, pola súa xenericidade, teñen pouco que aportar arredor da sorte das remanentes estruturas municipais da Gallaecia tardo-antiga en concreto. O único testemuño específico, no marco xeográfico do reino suevo e da amplificada Gallaecia visigoda temperá, concretamente na contorna da lusitana Idanha, atopámolo nunha comunidade consignada no Parroquial suevo como Municipio e no numerario visigodo como MONECIPIO (Fig. 1) ${ }^{85}$. Xa o padre P. David se preguntou lexitimamente

\footnotetext{
${ }_{81}$ Arredor dos aspectos formais das emisións galaico-visigodas, véxase Pliego VÁzQuEz, "Gallaecia...”, páxs. 93-96.

82 Cfr. Fernández Calo, Estado..., páxs. 296-299.

${ }^{83}$ Nomeadamente, curiais en Lib. iud., V, IV, 19; defensores en XII, I, 2; II, I, 25. Cfr. HinoJosA, "El origen...", páxs. 4-5; e sobre todo Pérez Pujol, Historia..., páxs. 259 e segs.

${ }^{84}$ Sánchez-Albornoz, Ruina..., páxs. 99 e segs.

85 Par., VII, 2; Pliego VÁzquez, "La moneda...”, páx. 127.
} 
se este topónimo non implicaría na comunidade que designou a pervivencia tardo-antiga da organización municipal romana ${ }^{86}$. Coido que o mero topónimo non aporta un argumento de xuízo decisivo, pois podería tratarse simplemente da fosilización do antergo título constitucional da comunidade na súa propia denominación ordinaria. Máis ben cómpre recoñecermos que non contamos con argumentos nin a favor nin en contra desta posibilidade.

Do mesmo xeito, nada se opón a que o municipium sobrevivise na Gallaecia visigoda, nun contexto, con todo, no que alén das xenéricas fontes lexislativas non só non temos datos específicos senón que mesmo esvaece a que fora a principal evidencia desta realidade socio-política no antecedente período suevo-católico. Mais a partires da conquista visigoda tamén constatamos que unha das facetas comunitarias que satisfacera o réxime municipal, se cadra a máis significativa no referente aos sistemas de representación popular, sufriu unha transcendental redefinición ao abeiro do influxo do dereito xermánico. Pero con isto entramos xa na terceira herdanza cultural da Gallaecia tardo-antiga, merecedora, coma as anteriores, dunha atención particularizada.

\section{CONUENTUS, COMITIUM, THING: A SÍNTESE REPRESENTATIVA VISIGODA}

A lexislación visigoda enxerga un fulcral aspecto da representación popular na figura do conuentus, institución concretada segundo diferentes fórmulas, das que a máis completa sería o conuentus publicus uicinorum, "reunión pública dos veciños". Nesta expresión temos referencia explícita ao corpo civil da comunidade local —o conxunto dos seus uicini- e ao seu organismo representativo: o conuentus publicus. Esta alusión aos uicini como corpo civil pode confrontarse co concepto xurisdicional homónimo de uicinum, que aparece xa no Parroquial suevo como designación do ámbito xurisdicional local dalgunhas cidades episcopais $^{87}$, repetíndose na lexislación visigoda, onde do mesmo xeito denota afinidade xurisdicional ${ }^{88}$. Atopamos, pois, unha base firme para postularmos a correspondencia dos uicini cos habitantes do distrito local, e canda isto a do conuentus visigodo a unha idéntica influencia xeográfica. O uicinum, na súa acepción xurisdicional, non discriminou como vemos os ámbitos urbanos: cumpriría así admitir, canda E. Hinojosa, a incidencia dos conuentus visigodos tanto nas comunidades urbanas coma nas rurais ${ }^{89}$.

O conuentus congregaba puntualmente aos uicini ou corpo civil dun distrito local para trataren en común asuntos de carácter xurídico. Á luz das fontes lexis-

\footnotetext{
${ }^{86}$ David, Études..., páx. 79.

${ }^{87}$ Par. I, 1; II, 1; XII, 1, segundo a miña propia hipótese interpretativa desta fonte (véxase a nota 77).

${ }_{88}$ Así, en Lib. iud., IX, 1, 8.

${ }^{89}$ Hinojosa, "El origen...", páx. 5.
} 
lativas que o constatan, esta instancia representativa semella ter normalmente un rol pasivo e fugaz, limitándose ao testemuño público na execución de determinadas penas $^{90}$; pero unha lei de Recesvinto arredor de gando ceivo enxerga unha meirande influencia ${ }^{91}$ :

Será lexítimo apropiarse de cabalos ou [doutros] animais ceivos; mais quen os atope, anuncie [o achado] ao bispo, ao conde, ao xuíz ou aos señores do lugar, ou ben ao "conuentus" público dos veciños: quen non o faga, incurrirá en delito de furto.

A mención do conuentus como instancia de denuncia, canda o bispo, o conde, o xuíz ou o señor, enxerga o seu carácter netamente estrutural. Cabe pensar, pois, a habitual convocatoria destes conuentus, representación popular do territorium, para tomar testemuño público de determinados actos — como é o caso da lei reproducida-; pero tamén para deliberar arredor de problemas de interese xeral, exercendo algunha influencia, xa que logo, sobre o goberno local ${ }^{92}$.

Segundo E. Hinojosa, o conuentus visigodo sería de orixe xenuinamente xermánica ${ }^{93}$; e o certo é que semella a todas luces asimilábel á institución pan-xermánica do thing (gótico peihs), asemblea de carácter deliberativo que comprometía aos homes libres dunha comunidade ${ }^{94}$. Este órgano representativo fora primitivamente latinizado por Tácito como concilium $^{95}$; pero nada se opón a que o conuentus visigodo, que compartiu a súa mesma función política, reproduza unha forma evoluída ou simple denominación alternativa da mesma institución, nun contexto no que - por deriva semántica - a primeira voz pasara a designar estritamente os concilios eclesiásticos.

A proxección territorial ordinaria do thing era o gaus, equivalente xermánico do pagus latino ${ }^{96}$. Non estará de máis lembrarmos, a este respecto, o Parroquial e o seu testemuño dos pagi como denominación xeral, e singular no noso rexistro

\footnotetext{
90 Así, Lib. iud., VII, 4, 7; VIII, 1, 3; IX, 2, 2-3; IX, 3, 3.

${ }^{91}$ Ibíd., VIII, 5, 6: caballos uel animalia errantia liceat occupare, ita ut qui inuenerit denuntiet, aut sacerdoti, aut comiti, aut iudici, aut senioribus loci, aut etiam in conuentu publico nicinorum. Quod si non denuntiauerit, furis damnum habebit [...]. Adaptado de Karl Zeumer, Leges Visigothorum, Hannover-Leipzig, Monumenta Germanica Historica, 1902, páxs. 347-348. Traduzo sacerdos por “bispo" porque é ben sabido que na Tardoantigüidade este título estivo decote restrinxido ao episcopado, e de feito outras versións manuscritas da mesma fonte consignan expresamente episcopo: cfr. ibíd., páx. 348, nota viii, 5, 6.

${ }^{92}$ Cfr. Pablo C. Díaz Martínez, "El reino visigodo en vísperas del 711: sistema político y administración”, Zona Arqueológica, XV, 1 (2011), páx. 37.

93 Hinojosa, "El origen...", páx. 5.

${ }^{94}$ Cfr. Frode Iversen, "Concilium and Pagus: Revisiting the Early Germanic Thing System of Northern Europe", Journal of the North Atlantic (special volume), 5 (2013), páx. 5.

95 Véxase, nomeadamente, Tácito, Germania, 12.

96 IVERSEN, "Concilium...".
} 
histórico, dos distritos rurais locais ${ }^{97}$. Isto volve redundar na proxección local do conuentus visigodo; pero tamén podería suxerir un precedente suevo do acomodo das institucións locais galaicas a esta estrutura organizativa de influxo xermánico.

Emporiso, cómpre non reducirmos univocamente ao "xermanismo" a interpretación histórica do conuentus visigodo ${ }^{98}$. Non falta mesmo quen o atribúe a un antergo substrato céltico ${ }^{99}$; pero coido que dentro dos nosos limitados obxectivos abondará con confrontarmos os precedentes inmediatos. Xa E. Pérez Pujol forneceu a este respecto unha lei de Constantino que obrigaba a dar conta aos uicini de toda transacción de propiedade, reproducindo pois a función esencial, e mesmo o corpo civil, que as fontes visigodas atribúen ao conuentus ${ }^{100}$. Ademais, ao longo do Occidente romano, comunidades rurais de diversa consideración organizaron concilia, conciliabula e fora dotados de funcións políticas semellantes ás que podemos presumir para o conuentus visigodo. O forum, en concreto, chegou a ser o eixo do ordenamento político e urbano dalgunhas comunidades rurais da Gallaecia alto-romana $^{101}$. Semella pois que os horizontes romano e xermánico contan con precedentes de institucións análogas ao conuentus visigodo, institución que se antolla así resultado dunha síntese cultural máis ca dunha única herdanza exclusiva.

Neste senso, a herdanza romana concretaríase na vertente asemblearia do municipium, limitada aos comitia electivos ${ }^{102}$. Certamente, a comunidade de municipes implicada polos comitia municipais evoca unha vida civil ben máis avanzada cá comunidade de uicini do conuentus visigodo. Entre o municeps e o uicinus enxérgase unha evidente retracción da implicación pública do cidadán, na que resta o reforzamento da identidade privada e familiar fronte á civil e comunitaria. Neste tránsito houbo de influír sen dúbida o influxo xurídico do thing, traído polos continxentes xermánicos; mais tamén a propia evolución paulatina das estruturas sociais e materiais da nosa Tardoantigüidade, no contexto da tendencia á autarquía que, case topicamente, se adoita atribuír a esta época ${ }^{103}$. Porén, no conuentus albiscamos tamén un decisivo reforzamento da representación comunitaria directa, fronte á indirecta — curial — romana. Abofé, se cadra nesta renovada transformación dos órganos representativos, motivada polo enriquece-

\footnotetext{
97 Fernández Calo, "Plinio...", páxs. 187-189.

98 Para unha síntese xeral das diferentes perspectivas institucionalistas para a atribución cultural do dereito hispano tardo-antigo, véxase Carlos Alonso del ReAl, Esperando a los bárbaros, Madrid, Espasa-Calpe, 1972, páxs. 232 e segs., favorábel — coma nós—á noción de síntese de herdanzas diversas.

99 Así, André Pena Graña, Treba y Territorium: génesis y desarrollo del mobiliario e inmobiliario arqueológico institucional de la Gallaecia, tese de doutoramento inédita, Universidade de Santiago de Compostela, 2004, páx. 537.

${ }^{100}$ Pérez Pujol, Historia .., páx. 312; cfr. Codex Theodosianus, III, 1, 2.

${ }^{101}$ Cfr., con ampla bibliografía específica, Fernández CAlo, Estado..., páxs. 137-138.

${ }^{102}$ Así, por exemplo, Lex Flauia Malacitana, 53; para unha síntese xeral, véxase Julio Mangas, Leyes coloniales y municipales de la Hispania romana, Madrid, Arco Libros, 2001, páx. 50.

${ }^{103}$ Para unha revisión crítica, véxase SÁnchez PARdo, "Sobre las bases...”, páxs. 1006-1007.
} 
mento mútuo de dúas tradicións xurídicas dispares, radique o verdadeiro motivo da aparente retracción das noticias alusivas ao municipium visigodo. As curias galaicas, se se mativeron como semella ata o século VI, puideron desaparecer non en función da súa longuísima agonía, segundo preconizaba C. Sánchez-Albornoz $^{104}$, senón polo seu desfase verbo ás novas necesidades da sociedade tardo-antiga e a competencia da renovada instancia asemblearia, o conuentus.

Alén das xenéricas fontes lexislativas, non contamos con testemuños específicos da incidencia do conuentus visigodo na Gallaecia. Porén, do mesmo xeito que os precedentes romanos serviron para calibrarmos a complexa herdanza cultural desta institución, outros indicios diacrónicos poden apoiar a noción da súa incidencia efectiva na Gallaecia visigoda. Atopamos, neste senso, un posíbel precedente na enigmática conuencio Sueuorum de Lugo, aparente institución análoga e da mesma familia léxica có conuentus visigodo, citada no preámbulo do Parroquial suevo ${ }^{105}$ :

De lida a epístola do rei Teodomiro, os bispos decidiron no sínodo que a sé lucense fose metropolitana, coma Braga; pois alí estaba o confin para os bispos colindantes, e en Lugo sempre era grande a "conuencio" dos suevos.

Non é moito o valor que lle podemos dar agora a esta noticia, considerada apócrifa fronte á listaxe eclesiástica xenuína do Parroquial suevo. Segundo algunhas achegas recentes, entre as que hei de incluírme, tal circunstancia non desbota a veracidade dos feitos consignados por esta fonte ${ }^{106}$; pero mesmo de admitilo sen reservas apenas poderiamos adiantar nada da conuencio Suеuоrum a partires dunha noticia tan parca coma a que a testemuña. Poida que o termo teña o senso de "reunión" puntual, pero podería telo tamén, simplemente, de "conxunto" dos suevos de Lugo. Abonde con concluírmos que nesta conuencio Sueuorum temos un plausíbel, mais só conxectural, precedente do conuentus visigodo na Gallaecia, que nas súas implicacións máximas avalaría o temperán desenvolvemento na nosa terra da mesma síntese institucional á que nos temos referido.

Emporiso, é outro indicio diacrónico, pero posterior, o de meirande interese para nós. No Alto Medievo galego, en efecto, atopamos un claro candidato á herdanza do conuentus visigodo no concilium, asemblea de carácter xurídico e

\footnotetext{
${ }^{104}$ Véxase a nota 84.

${ }^{105}$ Par, praef: dum hanc epistolam [Theodemiri regis] episcopi legerunt, elegerunt in sinodo ut sedes Lucensis esset metropolitana sicut et Bracara, quia ibi erat terminus de confinitimis episcopis, et quia ad ipsum locum Lucensem grandis semper erat conuencio Sueuorum. Adaptado de DAVID, Études..., páx. 31. ${ }^{106}$ Díaz Martínez, El reino..., páx. 230; Jorge de Alarcão, "Os limites das dioceses suevas de Bracara e de Portucale”, Portugalia, 36 (2015), páx. 36; Fernández Calo, “Os synodi...”, páxs. 128-133.
} 
consultivo, que implicaba aos filii bene natorum e ás autoridades civís e relixiosas dunha comunidade. Unha pequena discrepancia podería albiscarse precisamente nestes suxeitos de representación que, como ten sintetizado F. López Alsina, equivalen á comunidade de domini ${ }^{107}$. Porén, este atranco non semella absoluto: os uicini implicados polo conuentus visigodo eran tamén homes libres e probabelmente propietarios, donos de cadanseu fundus, o que xustificaría a súa participación pública; e para nós, a súa admisíbel consideración como domini, soberanos de cadansúa domus, casa familiar. Estamos, coido, perante a mesma "cidadanía" alto-medieval que G. Bois conceptualizou para a Borgoña anterior ao ano mil, na que todo home libre tiña responsabilidades públicas no marco estrito do condado, antes de que as últimas estruturas "republicanas" da vella ciuitas romana sucumbiran perante as formas de poder patrimonializado feudal ${ }^{108}$. Se cadra o concilium alto-medieval galego comporte unha meirande exclusividade có conuentus visigodo; mais esta discrepancia, apenas relativa, de ningún xeito semella recusar a nidia xenealoxía entrambas institucións.

Admitido isto, o concilium alto-medieval non fai senón apoiar a incidencia efectiva do conuentus visigodo na Gallaecia. No noso Alto Medievo, os poderes locais continuaron a súa evolución sen solución de continuidade, malia o colapso visigodo do 711, pendentes do paulatino desenvolvemento de novas estruturas estatais, que se farían agardar, por mor da superficialidade da conquista islámica, ata o afianzamento asturiano do século IX ${ }^{109}$. Isto significa que o entramado institucional local deste período resposta fundamentalmente á remanencia post-visigoda, e que a presenza do concilium ha de ser entendida como un resultado do protagonismo que o conuentus, o seu devanceiro institucional, tivera na Gallaecia visigoda. Mais o abeiro do concilium pode dar pé a explorarmos outras das características concretas que definiran ao conuentus visigodo na Gallaecia. Neste senso, a presidencia do tenente de commissum nos concilia alto-medievais ${ }^{110}$ podería suxerir o rol dun cargo equivalente, se cadra o comes ciuitatis ou territorii ${ }^{111}$, nos conuentus visigodos. Porén, o contributo máis relevante, por redundar nas sospeitas que xa temos formulado, é a proxección local destes órganos representativos: a terra ou commissum, distrito ao que se vinculaba o concilium $^{112}$, non

\footnotetext{
${ }^{107}$ LóPez Alsina, La ciudad..., páx. 210.

${ }^{108}$ Guy BoIs, La revolución del año mil, Barcelona, Crítica, 1991, páxs. 52-54.

${ }^{109}$ Véxanse, por exemplo, López Carreira, O reino..., páxs. 149 e segs.; Fernández Calo, Estado..., páxs. 323-327.

${ }^{110}$ López Alsina, La ciudad..., páx. 210.

${ }^{111}$ Arredor do comitatus visigodo, véxanse P. D. KING, Law and Society in the Visigothic Kingdom, Cambridge, Cambridge University Press, 1972, páxs. 53-54; DíAz MarTínez, "El reino...”, páx. 39; FernáNDEz Calo, Estado..., páxs. 296-299.

${ }^{112}$ López Alsina, La ciudad..., páx. 210.
} 
é senón a estrutura xurisdicional herdeira do pagus ou territorium que identificamos na nosa Tardoantigüidade.

\section{UNHA DEFINICIÓN UNITARIA: A PLEBS CHRISTIANA}

Neste estudo, adicado estritamente á comunidade local, estamos a eludir outros aspectos, se cadra máis significativos, que compuxeron tamén a identidade social na nosa Tardoantigüidade. Así, malia a nosa atención global á dimensión comunitaria dos pagi e territoria, cada unha destas entidades locais parcelouse realmente en múltiples instancias de dependencia rexia e señorial ${ }^{113}$, de xeito que a súa expresión identitaria viuse restrinxida polo poder das elites sociais e das súas redes clientelares. Vimos de suxerir, de feito, a limitación aos domini dunha institución de carácter tan "popular" coma o conuentus visigodo. Nin que dicir ten que o réxime municipal, paradigmática expresión do autogoberno local cuxa remanencia tamén enxergamos na nosa Tardoantigüidade, foi perante todo un instrumento político das elites locais: o ordo curialis, que excluía ao conxunto dos municipes dunhas verdadeiras atribucións gobernativas. E outro tanto cómpre engadirmos mesmo das comunidades de organización non civil, nas que o parentesco favoreceu probabelmente determinadas liñaxes preponderantes, e dende logo aos grandes cabezas de familia, como ostentadores exclusivos do poder local. En efecto, a poboación común, os minores xuridicamente diferenciados na lexislación penal visigoda ${ }^{114}$, viuse probabelmente relegada mesmo das expresións máis comunitarias do poder local. Podemos presumir ademais, sen moita marxe de erro, que as mulleres, os nenos e os escravos careceron mesmo das atribucións políticas que puideron chegar a disfrutaren estes minores.

Porén, entre a excepcional diversidade de dominios políticos, herdanzas culturais e réximes xurídicos dos que nos fomos ocupando nos apartados precedentes, existiu tamén un factor globalizador que non só unificou — agás primitivamente, se cadra, ás futuras igrexas étnicas - o multifacético panorama das comunidades locais da nosa Tardoantigüidade, senón que mesmo integrou na súa dimensión representativa aos sectores sociais máis marxinados. Este factor é, evidentemente, o relixioso.

No Occidente tardo-antigo vai ser, abofé, a relixión cristiá e a súa expresión institucional, a Igrexa, quen principalmente dote de contido á identidade comunitaria, e a comunidade local non foi unha excepción. Fronte ao plano civil, o

\footnotetext{
${ }^{113}$ Cfr., arredor da autoridade señorial, DíAz MarTínez, "La Hispania...”, páxs. 407-408; arredor das terras públicas (Fiscus) e as autoridades asociadas, GARCíA Moreno, Estudios..., páxs. 22-25; arredor da confluencia destas instancias de poder na Gallaecia tardo-antiga, SÁnchez PARdo, "Sobre las bases..."; Fernández Calo, Estado..., páxs. 310-312.

${ }^{114}$ Así, por exemplo, Lib. iud., VII, 5, 1.
} 
relixioso unificaba a entidade xurídica de toda a comunidade leiga, a plebs Christiana obxecto do ministerio pastoral e sacramental do clero ${ }^{115}$. Cómpre non sobreestimarmos este factor, pois a plebs foi evidentemente un suxeito pasivo na liturxia - que non na experiencia relixiosa, e nin sequera, puntualmente, no goberno eclesiástico ${ }^{116}$ - da Gallaecia tardo-antiga, dirixida por un clero de cuxo dereito de ordenación se excluía tamén a boa parte da poboación, incluídos os varóns con cargas servís ${ }^{117}$. Con todo, nesta plebs atopamos sen dúbida a expresión máis totalizadora e unívoca, fronte ás instancias civís que xa temos estudado, da identidade comunitaria tardo-antiga.

No cristianismo pre-niceno cada igrexa local era esencialmente autónoma; e esta peculiaridade, malia verse matizada pola implantación da xerarquía metropolitana, ficou como base do goberno episcopal. No proceso de evanxelización rural, cuxo pulo coincidiu na Gallaecia — como xa temos avanzado- co período suevo-católico, mantívose, por tradición ou necesidade, un principio semellante de comunidade local co gallo da organización do culto nas igrexas parroquiais: as mesmas que consigna o Parroquial suevo e que equivalían, como expuxemos, a cadansúa comunidade civil, ou plebs Christiana na súa expresión relixiosa. $\mathrm{Na}$ Gallaecia contamos con significativos testemuños deste concepto político-relixioso dende o século III $^{118}$, atribuído máis adiante por Hidacio de Chaves ás comunidades leigas que se enfrontaron aos suevos ${ }^{119}$. Mais é sobre todo un canon suevo-católico arredor das visitas pastorais dos bispos a estas igrexas parroquiais quen nos aporta, xa no contexto cronolóxico estrito do presente estudo, a evidencia expresa da identidade popular cristiá, a referida plebs Christiana, singularizada en cada unha das comunidades locais da Gallaecia tardo-antiga ${ }^{120}$ :

\footnotetext{
${ }^{115}$ Arredor da concepto de plebs ou populus cristián, na que entran esta e outras acepcións, tanto máis amplas como máis restritas, véxase, en síntese, Valerio NERI, "Concetto politico e concetto ecclesiale di populus nella tarda antichità”, en Popoli e Potere nel Mondo Antico, Pisa, ETS, 2005, páxs. 215-232.

${ }^{116}$ Cfr., nomeadamente, Luce Pietri, Yvette Duval e Charles Pietri, "Peuple chrétien ou plebs: le rôle des laïcs dans les élections ecclésiastiques en Occident", en Institutions, société et vie politique dans l'Empire romain au IV siècle ap. J.-C., Roma, École Française à Rome, 1992, páxs. 373-395. Na Gallaecia baixo-romana temos un significativo testemuño da virulenta implicación da plebs nas ordenacións episcopais, co gallo do cisma priscilianista: Conc. Tol. I, Exemplar definitivae...

${ }^{117}$ Conc. Brac. II, cap. Mart., 46.

${ }^{118}$ Véxase Fernández CALO, "Transformacións...", páx. 41.

${ }^{119}$ Hyd., Chron., 91 [81]; 113 [105]; 233 [229]; 239 [235]. Arredor das implicacións político-relixiosas do emprego hidaciano do termo, véxanse DíAz MARTínez, El reino..., páxs. 175-176; e sobre todo FerNáNDEZ CALO, "Transformacións...", páxs. 39-42.

${ }^{120}$ Conc. Brac. II, 1: [...] postquam ergo haec suos clericos discusserint uel docuerint episcopi, alio die conuocata plebe ipsius ecclesiae doceant illos, ut errores fugiant idolorum uel diuersa crimina, [...] et ut resurrectionem omnium hominum et diem iudicii, in qua unusquisque secundum sua opera recepturus est: et sic postea episcopus de ecclesia illa proficiscatur ad aliam. Adaptado de Juan TeJADA y Ramiro, Colección de cánones y de todos los concilios de la Iglesia de España y de América, vol. II, Madrid, Imprenta Real, 1810, páxs. 624-625. Óptase por esta edición pola súa accesibilidade, grazas á súa dixitalización.
} 
Logo de os bispos corrixiren e instruiren así aos seus cregos, outro día, convocado o pobo da mesma igrexa, instrúano para que fuxan dos erros dos ídolos e dos diversos crimes, [...] e arredor da Resurrección de todos os homes e do Día do Xuizo, no que cadaquén recibirá segundo as súas obras. E así, finalmente, o bispo pasará daquela igrexa a outra.

Nas visitas pastorais, os bispos suevo-católicos debían xa que logo de predicaren ao pobo (plebs) convocado en cada igrexa parroquial. Do mesmo xeito, co seu elocuente peche, de ecclesia illa proficiscatur ad aliam, o canon introduce ademais a relación intrínseca de cada unha destas plebes coa súa igrexa parroquial. Por este canon podemos recoñecer, xa que logo, que a plebs Christiana xa non constituía no período suevo-católico unha realidade — por calificala nos termos actuais - "diocesana", senón que fora partillada entre as múltiples igrexas parroquiais como parte do proceso de evanxelización e de implantación eclesiástica no ager galaico. Enxérgase aquí, pois, unha verdadeira expresión político-relixiosa, sen dúbida a máis ampla, do corpo civil constituínte de cada comunidade local.

\section{CONCLUSIÓNS}

Arrombando agora as pescudas desenvolvidas ata aquí, podemos insistir na forte identidade civil que singularizou en si mesma a cada unha das comunidades da Gallaecia tardo-antiga, tanto en relación ás súas homólogas coma aos estados territoriais - suevo e visigodo - que se asentaron sobre elas. O presente estudo estruturouse en función das herdanzas culturais que influíron na identidade xurídica destas comunidades e nas súas instancias representativas; das que, xa tratadas en fondura, cómpre extraermos algúns resultados específicos:

$1^{\circ}$. - as "igrexas étnicas" que o Parroquial suevo consigna sobre todo no norte da Gallaecia adscríbense á fugaz retracción das súas estruturas civís e ao influxo eclesiástico bretón durante o século escuro suevo, mais non necesariamente ao seu meirande arcaísmo durante os períodos suevo-católico e visigodo nos que se constatan;

$2^{\circ}$. - a serie monetal Latina apoia a noción da pervivencia, en pleno século VI, das estruturas municipais nalgunhas comunidades da Gallaecia sueva, sobre todo ao longo da súa fronteira asturicense, pero tamén no seu fulcro centro-occidental;

$3^{\circ}$. - o conuentus visigodo, instancia representativa local documentada estritamente polas fontes lexislativas, adscríbese á confluencia cultural romano-xermánica mellor do que ao influxo exclusivo dalgunha destas dúas tradicións; 
$4^{\circ}$. - a incidencia efectiva desta institución na Gallaecia visigoda apóiase diacronicamente, se cadra, na enigmática conuencio Sueuorum, mais sobre todo no concilium alto-medieval galego, o seu claro herdeiro institucional;

$5^{\circ}$. - a diversidade cultural advertida no conxunto da nosa Tardoantigüidade semella terse ido diluíndo paulatinamente a prol dunha certa uniformización civil, a partires canda menos do período suevo-católico;

$6^{\circ}$. - a Igrexa desenvolveu paralelamente unha expresión político-relixiosa de meirande percorrido histórico cás anteriores, a plebs Christiana, que matizou a diversidade xurídica e cultural á que nos referimos, e a social no seo de cada comunidade local.

Como vemos, a comunidade local constituíu na nosa Tardoantigüidade unha realidade xurídica de seu, que evoluíu ao seu propio ritmo e da que emanaron autonomamente determinadas instancias representativas, condicionando a vida política dos seus habitantes e o desempeño dos dignatarios locais do Estado. Abofé, o aspecto representativo do que nos temos ocupado con exclusividade no presente estudo conformou só unha faceta parcial do desenvolvemento institucional destas mesmas comunidades. A atención ás devanditas instancias estatais sobre o poder local, en relación coas emanadas da propia comunidade, emerxe dos nosos resultados como unha ineludíbel tarefa pendente. Coido, en fin, que o presente estudo pode abrir un nidio vieiro co que encetarmos a exploración destoutros aspectos do poder local... Mais isto só poderá ser, se acaso, satisfeito no marco de futuras investigacións.

\section{BIBLIOGRAFÍA}

Alarcão, Jorge de, "Os limites das dioceses suevas de Bracara e de Portucale", Portugalia, 36 (2015), páxs. 35-48.

Alonso del Real, Carlos, Esperando a los bárbaros, Madrid, Espasa-Calpe, 1972.

Arias Vilas, Felipe, "Apuntes sobre a ocupación do territorio na Galicia Baixorromana: castros e vilas”, en Galicia da romanidade á xermanización: problemas históricos e culturais, Santiago de Compostela, Museo do Pobo Galego, 1993, páxs. 201-208.

Barroso Cabrera, Rafael, Morín de Pablos, Jorge, e Sánchez Ramos, Isabel, "Gallaecia Gothica: de la conspiración del Dux Argimundus (589/590 d.C.) a la integración en el Reino visigodo de Toledo", Idanha-a-Velha, 1 (2015), páxs. 1-156.

Beltrán Lloris, Francisco, "Un espejismo historiográfico: las organizaciones gentilicias hispanas", en G. Pereira Menaut (dir.), Actas del primer congreso peninsular de Historia Antigua, vol. II, Santiago de Compostela, Universidade de Santiago de Compostela, 1988, páxs. 197-234.

Bois, Guy, La revolución del año mil, Barcelona, Crítica, 1991.

Cabral, João M. Peixoto, e Metcalf, David Michael, A moeda sueva: Suevic Coinage, Porto, Sociedade Portuguesa de Numismática, 1997.

Camps, Gabriel, "Rex gentium Maurorum et Romanorum: recherches sur les royaumes de Maurétanie des VI ${ }^{\mathrm{e}}$ au VII ${ }^{\mathrm{e}}$ siècles", Antiquités Africaines, 20 (1984), páxs. 183-218. 
Cavada Nieto, María Milagros, "Monedas romanas de ceca hispana halladas en Galicia", Gallaecia, 13 (1992), páxs. 97-111.

Cebreiro Ares, Francisco, "Dificultades que plantea el estudio de la historia monetaria sueva", en Francisco Cebreiro Ares (ed.), Introducción a la Historia Monetaria de Galicia (s. II a.C.-XVII d.C.), A Coruña, Labirinto de Paixóns, 2012, páxs. 31-63.

David, Pierre, Études historiques sur la Galice et le Portugal du VIII ${ }^{e}$ au XII ${ }^{e}$ siècle, Lisboa-Paris, Portugalia-Les Belles Lettres, 1947.

Díaz Martínez, Pablo C., "Gallaecia: de Reino Suevo a provincia visigoda", en Gerardo Pereira Menaut (coord.), Galicia fai dous mil anos: o feito diferencial Galego, vol. I, Santiago de Compostela, Museo do Pobo Galego, 1997, páxs. 253-278.

Díaz Martínez, Pablo C., "El Parrochiale Suevum: organización eclesiástica, poder político y poblamiento en la Gallaecia Tardoantigua”, en Jaime Alvar (ed.): Homenaje a José María Blázquez, vol. VI, Sevilla, Ediciones Clásicas, 1998, páxs. 35-47.

Díaz Martínez, Pablo C., "Acuñación monetaria y organización administrativa en la Gallaecia tardoantigua”, Zephyrus, 57 (2004), páxs. 367-375.

Díaz Martínez, Pablo C., "La Hispania visigoda", en Pablo C. Díaz Martínez, Celia Martínez Maza e Francisco Javier Sanz Huesma, Hispania tardoantigua y visigoda, Madrid, Istmo, 2007, páxs. 257-612.

Díaz Martínez, Pablo C., El reino suevo (411-585), Madrid, Akal, 2011.

Díaz Martínez, Pablo C., "El reino visigodo en vísperas del 711: sistema político y administración", Zona Arqueológica, XV, 1 (2011), páxs. 31-42.

Fernandes, A. de Almeida, Paróquias suevas e dioceses visigóticas, Tarouca, 1997.

Fernández Calo, Martín, A organización político-administrativa de Galicia na Antigüidade (séculos II a.C.-VIII d.C.), tese de licenciatura inédita, Universidade de Santiago de Compostela, 2015.

Fernández Calo, Martín, "Plinio, o Parroquial Suevo, e a evolución estrutural do poder local galaico na Antigüidade", Gallaecia, 34 (2015), páxs. 175-207.

Fernández Calo, Martín, "Os synodi suevo-católicos: implicacións político-administrativas dunha bipartición metropolitana”, Cuadernos de Estudios Gallegos, LXIII, 129 (2016), páxs. 125-162.

Fernández Calo, Martín, "Transformacións e permanencia do municipium na Gallaecia baixo-romana", Cuadernos de Estudios Gallegos, LXIV, 130 (2017), páxs. 15-48.

Fernández Calo, Martín, Estado, poder e estruturas políticas na Gallaecia (séculos II a.C.-VIII d.C.), Santiago de Compostela, Blukk, 2018.

García Moreno, Luis A., Estudios sobre la organización administrativa del reino visigodo de Toledo, Madrid, Instituto Nacional de Estudios Jurídicos, 1974.

García Moreno, Luis A., "La Iglesia y el cristianismo en la Galecia de época sueva", Antigüedad y Cristianismo, 23 (2006), páxs. 39-55.

Marques, Mário Gomes, A moeda peninsular na idade das trevas, Sintra, Instituto de Sintra, 1998.

González García, Alberto, e Martínez Chico, David, "Hallazgo de un triente emeritense de la serie LATINA MVNITA en Cáceres (España)", Gallaecia, 25 (2016), páxs. 225-231.

González López, Emilio, “A monarquía suevo-galaica e a súa organización eclesiástica”, Grial, 42 (1976), páxs. 283-298.

Grierson, Philip, e Blackburn, Mark, Medieval European Coinage, vol. I, Cambridge, Cambridge University Press, 2006. 
Hinojosa, Eduardo de, "El origen del regimen municipal en León y Castilla", La Administración, s/n (1896), páxs. 3-24, dispoñíbel en <http://bibnum.enc.sorbonne.fr/tires-apart/132929546> [Consulta: 18/05/2017].

Isla Frez, Amancio, La sociedad gallega en la Alta Edad Media, Madrid, CSIC, 1992, páxs. 197-234.

Iversen, Frode, "Concilium and Pagus: Revisiting the Early Germanic Thing System of Northern Europe", Journal of the North Atlantic (special volume), 5 (2013), páxs. 5-17.

King, P. D., Law and Society in the Visigothic Kingdom, Cambridge, Cambridge University Press, 1972.

Le Roux, Patrick, "Las ciudades de la Callaecia romana durante el Alto Imperio", Gerión, 14 (1996), páxs. 363-380.

López Alsina, Fernando, La ciudad de Santiago de Compostela en la Alta Edad Media, Santiago de Compostela, Ayuntamiento de Santiago de Compostela, 1988.

López Carreira, Anselmo, O reino medieval de Galicia: contribución a unha historia política, Vigo, A Nosa Terra, 2008.

López Cuevillas, Florentino, La civilización céltica en Galicia, Santiago de Compostela, Porto y Cía, 1953.

López Quiroga, Jorge, El final de la Antigüedad en la Gallaecia: la transformación de las estructuras de poblamiento entre Miño y Duero (siglos V al X), A Coruña, Pedro Barrié de la Maza, 2004.

MacMullen, Ramsay, "The Celtic Renaissance”, en R. MacMullen, Changes in the Roman Empire: Changes in the Ordinary, Princeton, Princeton University Press, 1990, páxs. 41-48.

Mangas, Julio, Leyes coloniales y municipales de la Hispania romana, Madrid, Arco Libros, 2001.

Martin, Céline, "In confinio extremis gentibus: la percepción de la frontera en el reino visigodo", Studia Historica (historia antigua), 16 (1998), páxs. 267-280.

Martín Viso, Iñaki, "Circuits of Power in a Fragmented Space: Gold Coinage in the Meseta del Duero (Sixth-Seventh Centuries", en Julio Escalona e Andrew Reynolds (eds.), Scale and scale change in the Early Middle Ages: Exploring landscape, local society and the world beyond, Tunhout, Brepols, 2011, páxs. 215-252.

Marques, José, "Os municípios portugueses dos primórdios da nacionalidade ao fim do reinado de D. Dinis: alguns aspectos", Revista da Faculdade de Letras (Universidade do Porto), 10 (1993), páxs. 69-90.

Marques, Mário Gomes, e Ribeiro, José Cardim, "As legendas da série Latina Munita”, en $I V$ Congresso Nacional de Numismática, Lisboa, 1998, páxs. 69-98.

Merêa, Paulo, e Girão, Aristides de Amorim, "Territórios portugueses do século XI", Revista Portuguesa de História, 2 (1943), páxs. 255-263.

Metcalf, David Michael, "The coinage of the first and second Suevic kingdoms: from romanitas to latinization", en Galicia da romanidade á xermanización: problemas históricos e culturais, Santiago de Compostela, Museo do Pobo Galego, 1993, páxs. 355-365.

Monteagudo, Luis, "Carta de Coruña romana (iii): costa”, Emerita, 25 (1957), páxs. 14-80.

Moreno Casado, José, "Los concilios nacionales visigodos: iniciación de una política concordatoria", Boletín de la Universidad de Granada, 18 (1946), páxs. 1-51.

Neri, Valerio, "Concetto politico e concetto ecclesiale di populus nella tarda antichità", en Popoli e Potere nel Mondo Antico, Pisa, ETS, 2005, páxs. 215-232.

Núñez García, Óscar, Un novo deus para os galaicos: a cristianización de Gallaecia, Santiago de Compostela, Lóstrego, 2012. 
Núñez Meneses, Pablo, Historia monetaria de la Galicia medieval, tese de doutoramento inédita, Universidade de Santiago de Compostela, 2017.

Orlandis Rovira, José, "Las relaciones intereclesiales de la Hispania visigótica”, Communio, 12 (1972), páxs. 403-444.

Pena Graña, André, Treba y Territorium: génesis y desarrollo del mobiliario e inmobiliario arqueológico institucional de la Gallaecia, tese de doutoramento inédita, Universidade de Santiago de Compostela, 2004.

Pereira Menaut, Gerardo, "Los castella y las comunidades de Gallaecia", Zephyrus, 34-35 (1982), páxs. 245-268.

Pérez Pujol, Eduardo, Historia de las instituciones sociales de la España goda, vol. II, Madrid, Fernando Fe, 1896.

Pietri, Luce, Duval, Yvette, e Pietri, Charles, "Peuple chrétien ou plebs: le rôle des laïcs dans les élections ecclésiastiques en Occident", en Institutions, société et vie politique dans l'Empire romain au IV siècle ap. J.-C., Roma, École Française à Rome, 1992, páxs. 373-395.

Pliego Vázquez, Ruth, La moneda visigoda, vol. I, Sevilla, Universidad de Sevilla, 2009.

Pliego Vázquez, Ruth, "Gallaecia en tiempos del Reino Visigodo de Toledo: sus emisiones monetarias", en Francisco Cebreiro Ares (ed.), Introducción a la Historia Monetaria de Galicia (s. II a.C.-XVII d.C.), A Coruña, Labirinto de Paixóns, 2012, páxs. 65-104.

Ribeiro, José Cardim, "Da existência de nomes pessoais em legendas de tremisses da série Latina munita", en M. G. Marques, A moeda peninsular na idade das trevas, Sintra, Instituto de Sintra, 1998, páxs. 173-185.

Rivas Fernández, Juan Carlos, Antigüedad del episcopado auriense, Ourense, Duen de Bux, 2003.

Rodríguez Resino, Álvaro, Do imperio romano á alta idade media: arqueoloxía da Tardoantigüidade en Galicia (séculos V-VIII), Noia, Toxosoutos, 2005.

Roma Valdés, Antonio, "Emisiones monetarias del siglo VI d.C. con leyenda LATINA MVNITA: estado del debate", Brigecio, 12 (2002), páxs. 79-84.

Rousselle, Aline, Croire et guérir: la foi en Gaule dans l'Antiquité tardive, Paris, Fayard, 1990.

Sánchez-Albornoz, Claudio, Ruina y extinción del municipio romano en España e instituciones que le reemplazan, Buenos Aires, Universidad Nacional de Buenos Aires, 1943.

Sánchez Pardo, José Carlos, "Organización eclesiástica y social en la Galicia tardoantigua: una perspectiva geográfico-arqueológica del Parroquial Suevo”, Hispania Sacra, LXVI, 134 (2014), páxs. 439-480.

Sánchez Pardo, José Carlos, "Sobre las bases económicas de las aristocracias en la Gallaecia suevo-visigoda (ca. 530-650 d.C.): comercio, minería y articulación fiscal”, Anuario de Estudios Medievales, XLIV, 2 (2014), páxs. 983-1023.

Soares, Franquelim Neiva, "Os Concílios Suevos de Braga (561 e 572)", en Erwin Koller e Hugo Laitenberger (eds.), Suevos-Schwaben: das Königreich der Sueben auf der Iberischen Halbinsel (411-585), Tübingen, Gunter Narr Verlag, 1998, páxs. 63-79.

Suárez Piñeiro, Ana María, A romanización en Galicia, Noia, Toxosoutos, 2009.

Tejada y Ramiro, Juan, Colección de cánones y de todos los concilios de la Iglesia de España $y$ de América, vol. II, Madrid, Imprenta Real, 1810, dispoñíbel en $<$ https://books.google. es/books?id=FIvl_SAcvZ8C\&hl=es\&source=gbs_navlinks_s> [Consulta: 30/12/2018].

Tranoy, Alain, La Galice romaine: recherches sur le nord-ouest de la péninsule ibérique dans l'Antiquité, Paris, Diffusion de Boccard, 1981.

Ubric Rabaneda, Purificación, La Iglesia y los Estados bárbaros en la Hispania del siglo $\mathrm{V}$ (409-507), tese de doutoramento inédita, Universidad de Granada, 2003. 
Valdeón Baruque, Julio, "El origen del concejo abierto en Castilla y León”, en Miscel·lània en homenatge al P. Agustí Altisent, Tarragona, Diputació de Tarragona, 1991, páxs. 173-182.

Valiere, Paul, Conciliarism: A History of Decision-Making in the Church, Cambridge, Cambridge University Press, 2012.

Vigil, Marcelo, "Romanización y permanencia de estructuras sociales indígenas en la España septentrional", en Conflictos y estructuras sociales en la Hispania Antigua, Madrid, Akal, 1977, páxs. 129-137.

Wickham, Chris, Framing the Early Middle Ages: Europe and the Mediterranean (400-800), Oxford, Oxford University Press, 2005.

Yorke, Barbara, The Conversion of Britain: Religion, Politics and Society in Britain, c.600-800, London-New York, Routledge, 2014.

Young, Simon, Bretoña: camiños novos, Noia, Toxosoutos, 2002.

Zeumer, Karl, Leges Visigothorum, Hannover-Leipzig, Monumenta Germaniae Historica, 1902.

Zeumer, Karl, Historia de la legislación visigoda, Barcelona, Universidad de Barcelona, 1944. 